\title{
Novel microtubule-targeting agents - the epothilones
}

\author{
Kit L Cheng \\ Thomas Bradley \\ Daniel R Budman \\ 'Monter Cancer Center, North \\ Shore - LIJ Health Systems, Lake \\ Success, New York, USA
}

\begin{abstract}
Epothilones are a new class of antimicrotubule agents currently in clinical trials. Their chemical structures are distinct from taxanes and are more amenable to synthetic modification. Six epothilones have been studied in preclinical and clinical trials: patupilone (epothilone B), ixabepilone (BMS247550), BMS 310705, sagopilone (ZK-EPO), KOS-862 (epothilone D), and KOS-1584. In vitro data have shown increased potency in taxane-sensitive and taxane-resistant cancer cell lines. This enhanced cytotoxic effect has been attributed to epothilone being a poor substrate for $\mathrm{p}$-glycoprotein drug resistance protein and having high affinity to the various $\beta$ tubulin isoforms. Phase I clinical data have shown different dose-limiting toxicities for each of the epothilones. These effects are drug specific, dose specific, and schedule of administration specific. While diarrhea and myelosuppression are the dose-limiting toxicities for patupilone and BMS 310705, respectively, neurologic toxicity, as seen with taxanes, is the dose-limiting toxicity of ixabepilone, sagopilone, and KOS-862. In an effort to decrease neurologic toxicity, investigators have modified dosing schedules with limited success. Ixabepilone has the most mature clinical results with published phase II and III data, and regulatory approval for clinical use in the treatment of breast cancer. Ixabepilone has also been combined with other anticancer agents and has regulatory approval in combination with capecitabine for heavily treated breast cancer.
\end{abstract}

Keywords: microtubule-targeting agents, epothilones, taxanes, ixabepilone

\section{History}

Drugs that target tubulin are active in human malignant disease and are an essential component of medical treatment of these diseases (Budman 2005, Pellegrini and Budman 2005). Of this class of agents, a variety of active drug structures have been identified, with the vinca alkaloids, the taxanes, and the epothilones achieving regulatory approval for cancer treatment. As a result, pharmaceutical research on compounds that interfere with tubulin function has concentrated on agents which might have enhanced efficacy or reduced toxicity. A current Medline search for "tubulin binding drugs" yielded 430 references. An analogous search of the National Institutes of Health Clinical Trials Registry, http://clinicaltrials.gov, using the phrase "epothilone" lists 108 clinical studies in patients with malignant disease.

The epothilones were originally discovered in 1987 from the fermentation of soil bacteria found on the banks of the Zambesi River in Africa (Gerth et al 1996; Lee et al 2008). A myxobacterium, Sorangium cellulosum, was noted to produce biologically active substances. One chemical isolate, epothilone A, was noted to be highly cytotoxic (inhibitory concentration at $50 \%$ activity, $\mathrm{IC}_{50}=0.05 \mu \mathrm{M}$ ) in vitro when applied to the human T-24 bladder carcinoma cell line (Gerth et al 1996).

Natural products are a well recognized source of novel agents for anticancer development and such drugs are usually selected on the basis of functional screening (Shah and Kaye 2003). Epothilone, a macrolide compound, was selected for further 
development on the basis of demonstrated paclitaxel-like properties during preclinical screening of compounds binding to tubulin. Bollag et al (1995) used a novel microtubule filtration assay to rapidly screen large numbers of compounds to select agents which induced tubulin polymerization. Electron microscopy differentiated true polymerization induced by the screened compounds from nonspecific protein aggregation. Of 7000 test samples screened, 6\% of plant extracts and $0.5 \%$ of other sources (marine, insect, microbial) screened positive, one of them being epothilone. Although other natural products with similar in vitro taxane-like activity were isolated, epothilone's successful development can be credited to its easy synthesis in bulk from fermentation and its structure being amenable to modification (Bollag et al 1995). The original structures were epothilone A and B. Epothilones derived from fermentation are classified as either epoxides on the presence of an epoxide structure at C-12-C-13 (epothilones A, B, E, F) or olefins (epothilone C, D) (Fumoleau et al 2007). Semi-synthetic derivatives have subsequently been developed to enhance pharmacologic properties. Epothilones demonstrated greater cytotoxicity than paclitaxel with an $\mathrm{IC}_{50}$ in the low nanomolar range in a variety of tumor cell lines (Bollag et al 1995; Chou et al 1998; Lee et al 2001; Fumoleau et al 2007). The six agents that have reached clinical trials in man are discussed below (Table 1).

\section{Chemistry}

The National Institutes of Health maintains a web site, PubChem (http://pubchem.ncbi.nlm.nih.gov) which is invaluable for information on chemical, preclinical activity, and toxicology of drugs. Twelve epothilones are listed on this web site. Epothilones are structurally less complex and have a ring structure unrelated to that of paclitaxel. The critical structure is the macrolide ring with a thiazolecontaining side chain and a ketone (Figure 1). The only structural difference between epothilone $\mathrm{A}$ and $\mathrm{B}$ is that epothilone B (patupilone) has a methyl group at position
C12 (Figure 1). Patupilone is more hydrophilic than epothilone $\mathrm{A}(\mathrm{X} \log \mathrm{P}$, the partition distribution coefficient between water and octanol, is 2.1 vs 1.7 respectively). This small modification increases microtubule stabilization such that patupilone is twice as potent as epothilone A (Goodin et al 2004; Cortes and Baselga 2007). Epothilone A has poor pharmacologic properties with loss of structural stability in animal plasma which led to the agent being dropped from further studies (Lee et al 2008).

Structural modifications have also been made to improve drug solubility and in some cases to negate the need for solubilization in vehicles that may cause hypersensitivity reactions. Ixabepilone is a second-generation patupilone derivative with an azide group in place of oxygen on position 16 of the macrolide ring (Figure 1). Ixabepilone is more resistant to degradation by carboxylesterase than the parent compound (Goodin et al 2004). BMS-310705 is a water-soluble derivative of patupilone with a substitution of the hydroxyl group with an amino group in the $\mathrm{C} 21$ position of the methythiazole side chain. An analog of patupilone, ABJ879 (2-desmethyl-20-methylsulfanyl-Epo-B), is highly active in a taxane-resistant cervical cancer model and did reach phase I studies. No more information is available to date (Altmann and Memmert 2008). Modifications at specific positions on the macrolide ring enhance the in vitro activity. Sagopilone (ZK-EPO, ZK-219447) is the only fully synthetic third generation analog of patupilone, assembled from three building blocks (Alexander et al 2008). This drug was selected from a variety of analogs for further development because of its high potency in preclinical tumor models and its solubility in aqueous solutions (Klar et al 2006).

Desoxyepothilone B (KOS-862, epothilone D) lacks the $\mathrm{C} 12-13$ epoxide and is more potent than epothilone A in preclinical models utilizing ovarian cell lines that are resistant to taxanes (Nicolaou et al 1997; Goodin et al 2004). Hence, the epoxide ring is not a requirement for anticancer effect (Altmann 2005). A second generation

Table I Epothilone entities that have been studied clinically

\begin{tabular}{|c|c|c|c|}
\hline Agent & Origin & Solvent used clinically & Dose-limiting toxicity \\
\hline Patupilone & Natural product & Polyethylene glycol 300 & diarrhea \\
\hline BMS-3 10705 & 2nd generation epothilone B & aqueous & hematologic/hyponatremia \\
\hline Ixabepilone & 2nd generation epothilone B & Cremophor EL & hematologic/neurologic \\
\hline Sagopilone & 3rd generation epothilone $B$ & aqueous & neurologic \\
\hline Epothilone D & Lacks C 12-13 epoxide of B & Cremophor EL & neurologic \\
\hline KOS-I584 & 2nd generation epothilone D & aqueous & hepatotoxic/diarrhea \\
\hline
\end{tabular}




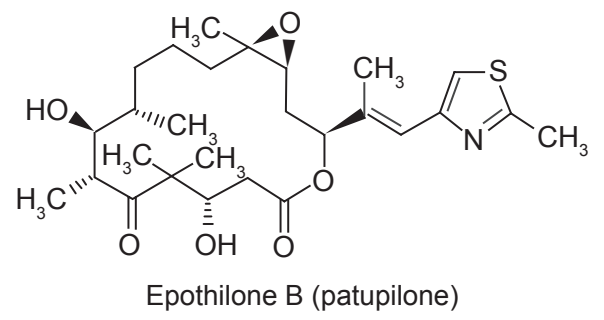<smiles>C/C(=C\c1csc(C)n1)[C@H](C[C@@H]1O[C@]1(C)CCC[C@@H](C)[C@H](O)C(C)C)NC(=O)C[C@@H](O)C(C)(C)C(=O)C(C)C</smiles>

BMS-247550 (ixabepilone, Ixempra ${ }^{\mathrm{TM}}$ )

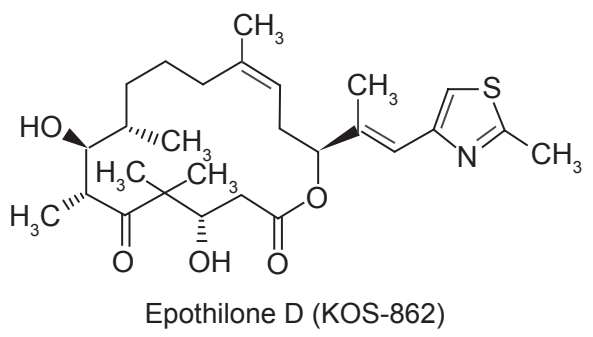

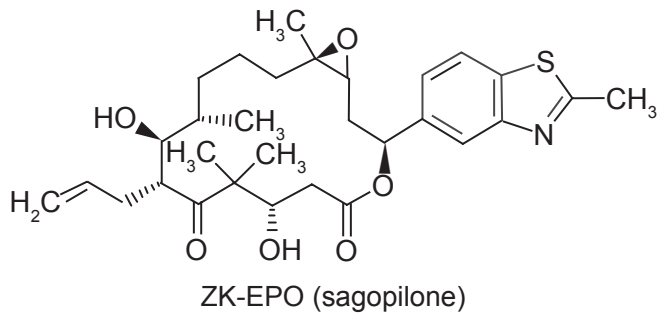

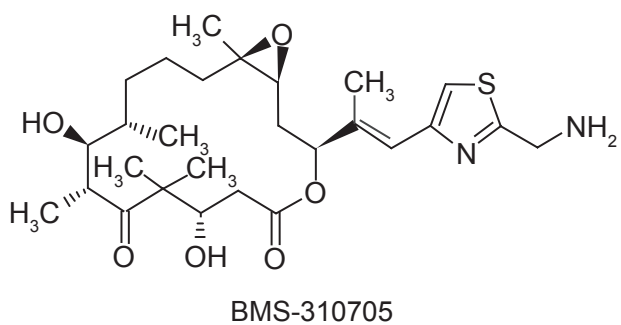

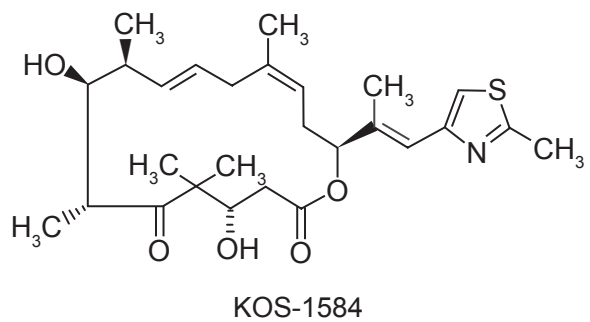

Figure I Chemical structures of the epothilones in clinical development. Reproduced from Alexander E, Rosa E, Bolos J, et al. 2008 . Sagopilone. Drugs Future, 33:496-505. Copyright Prous Science, S.A.U. or its Licensors. All rights reserved.

epothilone D analog, KOS 1584, has also been shown to have greater in vitro potency than patupilone or epothilone D (Fumoleau et al 2007).

\section{Structure/function activity}

Analogous to paclitaxel, epothilones bind to a common binding site on $\beta$-tubulin. A preclinical study in resistant cell lines also noted that both taxanes and epothilones share a common tertiary structure for binding to tubulin even though their chemical structures are distinct (Giannakakou et al 2000). The binding affinity of epothilone A to tubulin is of the same order of magnitude as the binding affinity of paclitaxel to tubulin based on competition assays. The $50 \%$ inhibitory concentration for displacement of $100 \mathrm{nM}$ of $\left({ }^{3} \mathrm{H}\right)$ paclitaxel from the tubulin binding site was $3.6 \mu \mathrm{M}$ for paclitaxel, $2.3 \mu \mathrm{M}$ for epothilone $\mathrm{A}$, and $3.3 \mu \mathrm{M}$ for patupilone (Nettles et al 2004). These studies indicate that taxanes and epothilones bind at or near the same site (Kowalski et al 1997).

However, other studies have suggested that the interactions by the pharmacophore of each agent within the binding pocket are not identical (Nettles et al 2004). These differences may reflect the differences in experimental conditions used to elucidate drug function (Reese et al 2006). In vitro studies of epothilone A bound to $\alpha, \beta$ tubulin in zinc-stabilized sheets demonstrate that epothilone $\mathrm{A}$ and paclitaxel share only one polar contact at $\mathrm{C}-7-\mathrm{OH}$ while the thiazole side chain of epothilone binds to a different region of $\beta$-tubulin not occupied by paclitaxel (Nettles et al 2004; Lee and Swain 2008). In addition, the methyl group at $\mathrm{C} 12$ seems to enhance a hydrophobic interaction between patupilone and $\beta$ tubulin that allows patupilone to be more potent than epothilone $\mathrm{A}$ (Kowalski et al 1997).

Nuclear magnetic resonance spectroscopy, electron crystallography, and molecular modeling have revealed further binding interactions of the epothilones with tubulin. The 16 member ring and part of the side chain reside within a hydrophobic region of $\beta$-tubulin. In the case of epothilone $\mathrm{A}$, hydrogen bonds bind $\mathrm{C} 1=\mathrm{O}, \mathrm{C} 3-\mathrm{OH}, \mathrm{C} 5=\mathrm{O}$, and $\mathrm{C} 7-\mathrm{OH}$ to tubulin at threonine 274 , arginine 278 , and arginine 282 residues of the M-loop. Hydrophobic interactions occur at the $\mathrm{C} 3$ to $\mathrm{C} 11$ portion of epothilone $\mathrm{A}$ (Nettles et al 2004). As previously noted (Altmann 2005), although initial studies indicated that the C12-13 epoxide was required for localizing the epothilone onto its tubulin 
target, more recent findings demonstrate that this moiety is not necessary as epothilone D is highly active as a tubulin binder (Nicolaou et al 1997).

\section{Preclinical functional activity}

Microtubules are present in all eukaryotes and are essential for the intracellular structure, cell division, and intracellular transport (Esteve et al 2007). These processes are regulated by polymerization and disassembly of the microtubule polymers. Disruption of these processes targets the cell for G2/M phase arrest resulting in apoptosis (Bhat and Setaluri 2007). Epothilones promote tubulin polymerization in vitro in the absence of microtubule associated proteins or guanosine triphosphate. These agents also prevent depolymerization of the microtubulin structure in the presence of calcium (Bollag et al 1995; Altmann et al 2004). Epothilones can also induce apoptosis at concentrations that do not cause mitotic cell cycle arrest. This cytotoxic effect is believed to be caused by disruption in the dynamic equilibrium between the intracellular pool of basic tubulin components ( $\alpha, \beta$ heterodimers) and the microtubule polymer (Chen and Horwitz 2002; Goodin et al 2004).

Using human MDA-MB-435 cells and fluorescence microscopy, investigators have noted a biologic difference in the spindle pole effects of epothilone A and of patupilone (Sakaushi et al 2008). These results suggest that small changes in the epothilone structure may have major differences in biological effect. Patupilone has recently been noted to cause mitochrondrial collapse with release of reactive oxygen species in sensitive cells thus leading to apoptosis (Khawaja et al 2008). Hence, these drugs have potent apoptotic promoting effects.

In vitro data demonstrate that patupilone at a concentration of $1 \mathrm{nmol} / \mathrm{L}$ has antiangiogenic properties when assayed using a human umbilical vein endothelial cell culture (Bijman et al 2006). The antiangiogenic activity has been related to interruption of microtubule dependent control of HIF-1 $\alpha$ (hypoxia inducible factor $1 \alpha$ ) translation (Escuin et al 2005). This anti-angiogenesis data suggests that these substances could potentially kill malignant cells at subtoxic concentrations in vivo by an alternative mechanism.

Attractive features of epothilones include their potency relative to taxanes and their activity in both taxane sensitive and in resistant cell lines (Kowalski et al 1997; Nicolaou et al 1997; Chou et al 1998; Goodin et al 2004; Mok et al 2006; Lee and Swain 2008) (Table 2). Epothilones have shown activity in ovarian, breast, lung, colon, prostate, squamous cell, fibroblast, and leukemia cell lines (Goodin et al 2004).
Ixabepilone demonstrated significant activity against the pediatric tumors - brain tumors, neuroblastoma, osteosarcoma, rhabdomyosarcoma, and Wilm's tumor - when grown in a murine model (Peterson et al 2005).

Patupilone has 3- to 20-fold higher in vitro cytotoxic potency compared with paclitaxel. In hepatocellular carcinoma cell lines, patupilone was 4 to 19 times more potent than docetaxel or paclitaxel (Table 2) (Mok et al 2006). Ixabepilone, a patupilone analog, has been shown to be 2.5 times more potent than paclitaxel in some cell lines (Table 2). In addition, ixabepilone has enhanced metabolic stability compared to the natural compounds (Lee et al 2001). Sagopilone, a synthetic patupilone analogue, acts in a taxanelike manner but is more cytotoxic than other epothilone derivatives in development (Hoffmann et al 2008). This analog demonstrates activity in taxane-resistant cell lines (Hoffmann et al 2008). Recent in vitro studies have noted that sagopilone is rapidly taken up into A549 epidermoid nonsmall cell lung cancer cells with localization of drug into the cytoskeleton and accelerated tubulin polymerization compared with paclitaxel or patupilone (Hoffmann et al 2008).

$\mathrm{P}$-glycoprotein (also known as MDR) is an active drug efflux pump that results in cellular resistance to many cytotoxic agents. Epothilones are poor substrates for P-glycoprotein and are cytotoxic in cell lines that express high levels of P-glycoprotein (Lehne 2000). The epothilones can demonstrate an order of magnitude more cytotoxic effect at a given dose compared to paclitaxel (Table 2) (Chou et al 1998). As recent genomic data has determined that $\mathrm{P}$-glycoprotein is over expressed in clinical samples of human Her2/neu+ breast cancer, these agents may be of particular value in this subset of patients $\left(\mathrm{O}^{\prime} \mathrm{Brien}\right.$ et al 2008). The different epothilones demonstrate varying susceptibility to P-glycoprotein mediated resistance. $\mathrm{ZK}-\mathrm{EPO}$ is not a substrate for this pump resistance protein (Stupp et al 2008). This drug is also highly active in cell lines expressing P-glycoprotein efflux pumps (Hoffmann et al 2008). Epothilone D is highly active in both taxane sensitive and taxane resistant cell lines (Lee and Swain 2008), while ixabepilone (BMS-247550) appears to be the most affected by P-glycoprotein expression but less so than paclitaxel (Table 2). Ixabepilone is 108 to 529 times more potent than taxanes or doxorubicin in the P-glycoprotein expressing hepatocellular carcinoma cell line SNU-449 (Mok et al 2006). While in vitro studies show patupilone to be potent, animal xenograft models have shown increased toxicity and a narrower therapeutic index of B compared with epothilone $\mathrm{D}$, suggesting a disassociation between the 


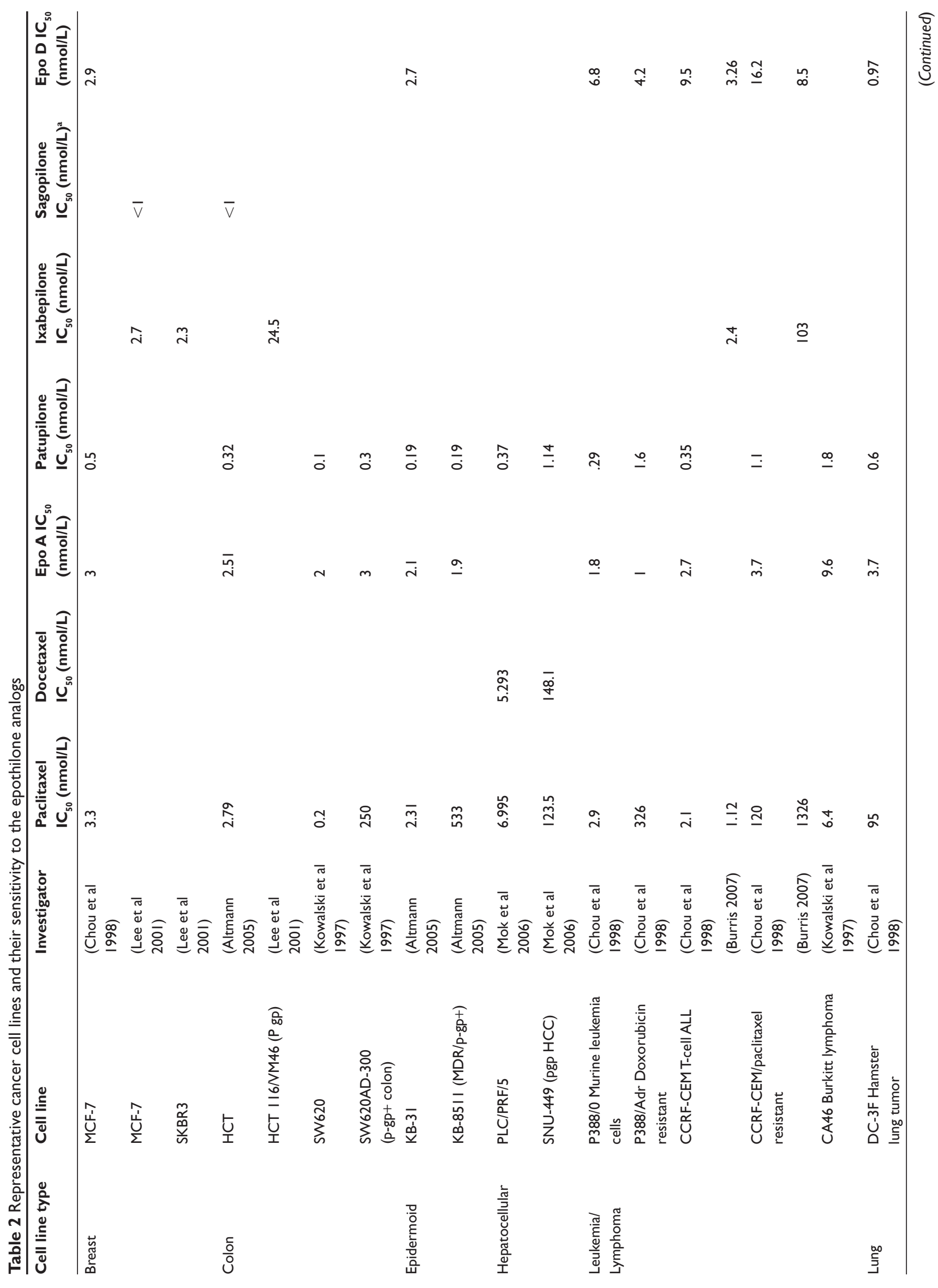




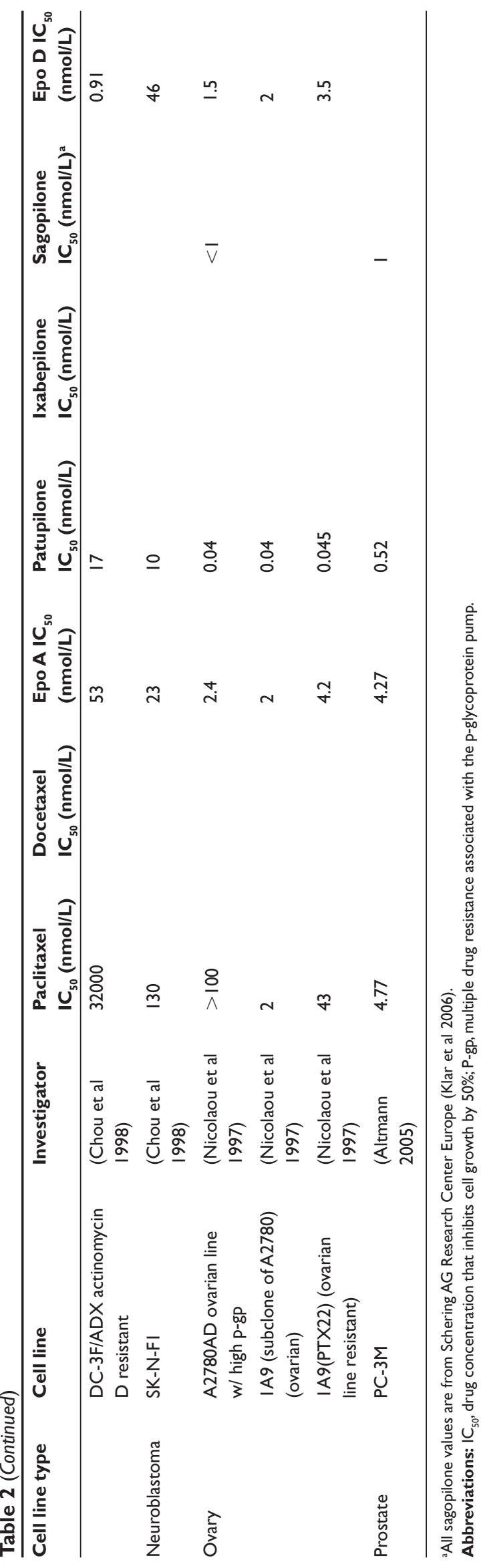

findings in cell lines and data from animal models (Chou et al 1998).

Through molecular modeling, microtubulin stabilizing agents have been found to have different affinities to $\beta$-tubulin isoforms. Paclitaxel has more affinity to $\beta \mathrm{I}$ than to the $\beta \mathrm{III}$ isoform (Magnani et al 2006). Increased $\beta \mathrm{III}$ isoform expression is one mechanism of increased resistance to paclitaxel (Magnani et al 2006; Seve et al 2005, 2008). In contrast, epothilone A has the same affinity for both isoforms (Magnani et al 2006).

Tubulin mutations are one cause of drug resistance in cultured cell lines as the target of these drugs is altered. Single point mutations in $\beta$-tubulin near the $\mathrm{M}$ loop at the nucleotide binding site and at the $\mathrm{COOH}$ terminus have been noted in some cancer cell lines. These sites are critical for the stabilization of microtubules. Point mutations in $\beta$-tubulin that confer resistance to epothilones are also associated with resistance to paclitaxel (Goodin et al 2004). One clinical study of 49 patients with nonsmall cell lung cancer suggested that paclitaxel resistance is associated with $\beta$-tubulin mutations (Monzo et al 1999). The significance of this finding is unclear, as tubulin mutations seem to be a rare occurrence in most human tumors (Berrieman et al 2004). In addition, tubulin mutations detected in non-small cell lung cancer samples isolated from patients were determined to be due to contamination of the genomic assay by amplification of pseudogenes which share homology. These resistance mutations therefore were not present in clinical specimens (Noguchi 2006).

Tubulin binding agents can activate the steroid and xenobiotic receptor, also known as the human pregnane $\mathrm{X}$ receptor. Pregnane $\mathrm{X}$ receptor is known to be a master switch in drug resistance. Activation of this pathway leads to enhanced expression of cytochrome CYP3A4 in both tumor cell lines and in mice which enhances metabolic degradation of drugs thus resulting in drug resistance (Mani et al 2005). This effect has been seen with epothilones as well as with taxanes (Mani et al 2005).

\section{Pharmacokinetics}

Phase I data have evaluated pharmacokinetic parameters using various dosing schedules (Table 3 ). The $\mathrm{C}_{\mathrm{p}} \max$ (maximal concentration of drug in the plasma) of these agents reaches the microgram per milliliter level in some of the schedules. A high volume of distribution is also commonly seen, suggesting high tissue binding. The half-lives of the various analogs varies from 7 to 89 hours and seems to differ depending upon the compound studied (Table 3). Apart from 
Table 3 Reported pharmacological parameters in the human phase I studies

\begin{tabular}{|c|c|c|c|c|c|}
\hline Drug & Investigator & Cp $(\mathrm{mg} / \mathrm{mL})$ & Vd (L) & Clearance (L/h) & TI/2 (hours) \\
\hline \multirow{5}{*}{$\begin{array}{l}\text { Patupilone } \\
\text { (Epothilone B) }\end{array}$} & (Rubin et al 2005) & & & 13 & 89 \\
\hline & (Reid et al 2008): $10 \mathrm{mg} / \mathrm{m}^{2}$ & & "similar values"a & "similar values"a & "similar values" \\
\hline & with normal hepatic & & & & \\
\hline & function or $5 \mathrm{mg} / \mathrm{m}^{2}$ & & & & \\
\hline & with hepatic dysfunction & & & & \\
\hline \multirow[t]{3}{*}{ BMS3I0705 } & (Mekhail et al 2003) & $40 \mathrm{mg} / \mathrm{m}^{2}=3936 \mathrm{ng} / \mathrm{mL}$ & Vss $443 \mathrm{~L} / \mathrm{m}^{2}$ & $277 \mathrm{~mL} / \mathrm{min} / \mathrm{m}^{2}$ & 42 \\
\hline & (Sessa et al 2003) & $5 \mathrm{mg} / \mathrm{m}^{2}=313 \mathrm{ng} / \mathrm{mL}$ & $133 \mathrm{~L} / \mathrm{m}^{2}$ & $16 \mathrm{~L} / \mathrm{h} / \mathrm{m}^{2}$ & 7 \\
\hline & & $25 \mathrm{mg} / \mathrm{m}^{2}=1680 \mathrm{ng} / \mathrm{mL}$ & $393 \mathrm{~L} / \mathrm{m}^{2}$ & $19 \mathrm{~L} / \mathrm{h} / \mathrm{m}^{2}$ & \\
\hline \multirow[t]{8}{*}{ Ixabepilone } & (Hao et al 2002) & & Vss-759.4 L/m² & $25.8 \mathrm{~L} / \mathrm{h} / \mathrm{m}^{2}$ & 39.1 \\
\hline & (Shimizu et al 2008) & $15 \mathrm{mg} / \mathrm{m}^{2}=62 \mathrm{ng} / \mathrm{mL}$ & $V s s=1910 \mathrm{~L}$ & $49 \mathrm{~L} / \mathrm{h}$ & 36 \\
\hline & & $30 \mathrm{mg} / \mathrm{m}^{2}=195 \mathrm{ng} / \mathrm{mL}$ & $1759 \mathrm{~L}$ & $43 \mathrm{~L} / \mathrm{h}$ & 43 \\
\hline & & $40 \mathrm{mg} / \mathrm{m}^{2}=313 \mathrm{ng} / \mathrm{mL}$ & II7I L & $32 \mathrm{~L} / \mathrm{h}$ & 43 \\
\hline & (Faivre et al 2008) & $15 \mathrm{mg} / \mathrm{m}^{2}=96-114 \mathrm{ng} / \mathrm{mL}$ & $475-677 \mathrm{~L}$ & $37-46 \mathrm{~L} / \mathrm{h}$ & $12-17$ \\
\hline & & $20 \mathrm{mg} / \mathrm{m}^{2}=186-193 \mathrm{ng} / \mathrm{mL}$ & $429-526 \mathrm{~L}$ & $30-32 \mathrm{~L} / \mathrm{h}$ & $13-17$ \\
\hline & & $25 \mathrm{mg} / \mathrm{m}^{2}=171 \mathrm{ng} / \mathrm{mL}$ & $755 \mathrm{~L}$ & $29 \mathrm{~L} / \mathrm{h}$ & 25 \\
\hline & & $30 \mathrm{mg} / \mathrm{m}^{2}=261 \mathrm{ng} / \mathrm{mL}$ & $595 \mathrm{~L}$ & $37 \mathrm{~L} / \mathrm{h}$ & 16 \\
\hline \multirow[t]{4}{*}{ Epothilone D } & (Spriggs et al 2003) & $16 \mathrm{mg} / \mathrm{m}^{2}$ to $626 \mathrm{ng} / \mathrm{mL}$ & $|2| \mathrm{L} / \mathrm{m}^{2}$ & $10 \mathrm{~L} / \mathrm{h} / \mathrm{m}^{2}$ & 9 \\
\hline & & $32 \mathrm{mg} / \mathrm{m}^{2}$ to $1623 \mathrm{ng} / \mathrm{mL}$ & & & \\
\hline & & $64 \mathrm{mg} / \mathrm{m}^{2}$ to $2215 \mathrm{ng} / \mathrm{mL}$ & & & \\
\hline & (Holen et al 2004) & $4 \mathrm{mg} / \mathrm{h}=200 \mathrm{ng} / \mathrm{mL}$ & $96 \mathrm{~L} / \mathrm{m}^{2}$ & $7 \mathrm{~L} / \mathrm{h} / \mathrm{m}^{2}$ & 10 \\
\hline \multirow[t]{3}{*}{ KOSI584 } & (Piro et al 2003) & & $95 \mathrm{~L} / \mathrm{m}^{2}$ & $5 \mathrm{~L} / \mathrm{h} / \mathrm{m}^{2}$ & 10 \\
\hline & $\begin{array}{l}\text { (Villalona-Calero et al } \\
\text { 2006) }\end{array}$ & $8.5 \mathrm{mg} / \mathrm{m}^{2}=78 \mathrm{ng} / \mathrm{mL}$ & $74 I \mathrm{~L}$ & $30 \mathrm{~L} / \mathrm{h}$ & 18 \\
\hline & $\begin{array}{l}\text { (Stopeck et al 2006; } \\
\text { Stopeck et al 2007) }\end{array}$ & $5 \mathrm{mg} / \mathrm{m}^{2}=122 \mathrm{ng} / \mathrm{mL}$ & $504 \mathrm{~L}$ & $20 \mathrm{~L} / \mathrm{h}$ & 19 \\
\hline
\end{tabular}

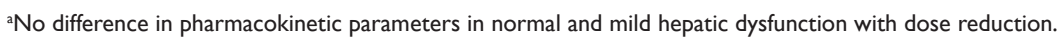

differences in the drug structures, the pharmacokinetic and pharmacodynamic effects in man may be partly attributed to the solvent required for clinical administration of drug. Some of these agents are poorly soluble in aqueous solutions and therefore need a co-solvent (Table 1) which may perturb drug distribution and elimination.

BMS-310705 is a water soluble patupilone derivative and thus has the advantage of not requiring premedications to prevent reactions to solvent (Table 1) (Sessa et al 2007). Sagopilone, is also water soluble (Alexander et al 2008). Other formulations, such as ixabepilone and epothilone D, are formulated in polyoxyethylated castor oil and require prophylactic histamine- 1 and histamine-2 blockers in order to avert hypersensitivity reactions induced by the solvents (Table 1). These adverse effects were previously well described for paclitaxel (Markman 2003).

Both patupilone and ixabepilone are metabolized by the liver. Excretion studies of radiolabeled ixabepilone found $52 \%$ of label excreted in the feces and $25 \%$ in the urine (Beumer et al 2007). Therefore liver dysfunction may affect clearance of the active drug. There are interpatient variabilities in drug disposition, especially with ixabepilone which is a substrate of cytochrome CYP3A4 (Goel et al 2008). Incubation of ixabepilone in human liver microsomes with different cytochrome inhibitors demonstrated that metabolism of ixabepilone was inhibited by $90 \%$ with a potent CYP3A4 inhibitor (ketoconazole). In humans, co-administration of ketoconazole with ixabepilone increased plasma $\mathrm{AUC}_{0-\infty}$ (total drug exposure in the plasma) by $79 \%$ with a small increase in $\mathrm{C}_{\mathrm{p}}$ max. In this dose ranging study, the maximum tolerated dose was decreased from $30 \mathrm{mg} / \mathrm{m}^{2}$ in patients with normal hepatic function to $25 \mathrm{mg} / \mathrm{m}^{2}$ in the presence of ketoconazole with dose-limiting toxicities of fatigue, neutropenia, mucositis, diarrhea, and febrile neutropenia (Goel et al 2008). In vitro studies indicate that patupilone is a weak inhibitor of CYP2C9, but a phase I study with warfarin did not show significant drug-drug interaction (Takimoto et al 2008). 


\section{Pharmacodynamics}

At present, there is no way to predict the effectiveness of these drugs in clinical medicine. Surrogate markers of efficacy and toxicity are needed. There are ongoing studies to correlate clinical response with microtubule bundle formation, tumor expression of microtubule stabilizing proteins, and post-translational changes in $\alpha$ tubulin (Pusztai 2007). Since epothilones have effects at concentrations lower than needed for microtubule bundle formation, the presence of microtubule formation may not serve as an effective surrogate marker.

In humans, microtubule bundle formation in peripheral blood mononuclear cells increased 1 hour after ixabepilone administration. Of note, there were different time courses of microtubule bundle formation in peripheral blood mononuclear cells compared with tumor cells, suggesting differential uptake and clearance (Mani et al 2004; Mani et al 2007; Lee and Swain 2008). Preliminary data did not indicate any change in efficacy in a mouse model with $\beta I I I$ isoform expression (Pusztai 2007). Increased expression of the $\beta I I I$ isoform has previously been implicated as a mechanism of paclitaxel resistance (Kamath et al 2005; Pusztai 2007).

While the ability to measure post translational changes (detyrosination and acetylation) to $\alpha$ tubulin has been correlated with microtubule stabilization and has increased after ixabepilone administration, this measurement does not correlate with clinical effectiveness of the drug (Zhuang et al 2007). The investigators have suggested several potential explanations: 1) microtubule engagement is insufficient to cause cell death, 2) death pathways must be activated, 3) the timing of post-treatment biopsies, or 4) threshold level of tubulin stabilization had not been reached. Tau protein expression, which is directly associated with estrogen expression, competes with tubulin-stabilizing agents for the same binding site and may confer resistance (Pusztai 2007).

\section{Human phase I studies}

Phase I data are available for: patupilone and its analogs (BMS-310705, sagopilone, ixabepilone), and epothilone $\mathrm{D}$ and its derivative (KOS-1584) (Table 4). The maximum tolerated dosages of the agents varies with the structure as do the toxicities. A variety of dosing schedules has been reported. Both dose and schedule are important in the generation of toxicities seen in man with all the epothilones studied to date.

Various schedules for the epothilones have been studied in order to modify adverse effects with varying degrees of success. The most distressing adverse effect is neurotoxicity, which occurs with the epothilone B analogs, but is not dose limiting with the epothilone D analogs (Table 4) (Fumoleau et al 2007). This problem is often dose limiting with taxane treatment (Markman 2003). Most patients in the published epothilone trials were previously treated with a taxane or platinum agent and thus may have had pre-existing clinical or subclinical neuropathy. Past studies have indicated that $\mathrm{C}_{\mathrm{p}}$ max of drugs may correlate with toxicities such as neurotoxicity or cardiotoxicity (Abraham et al 2003). Therefore, schedules that distribute the drug over time, such as a weekly or daily regimens, or prolonged infusion times have been investigated (Awada et al 2001; Burris et al 2002; Hao et al 2002; Abraham et al 2003; Spriggs et al 2003; Rubin et al 2005; Shimizu et al 2008).

\section{Patupilone}

Phase I studies have reported a variety of dosing schedules using a 5 minute bolus administration once weekly, administered 6 of 9 weeks, or 3 of 4 weeks, or once every 3 weeks, or daily for 5 days as a prolonged infusion (Table 4). Patupilone does not demonstrate schedule-dependent myelosuppression. It has not been associated with hypersensitivity reactions and may be administered with a shorter infusion time than the taxanes (Rubin et al 2005). In the weekly administration schedule, patients generally tolerated doses from 0.5 to $1.85 \mathrm{mg} / \mathrm{m}^{2}$ at the 6 of the 9 week schedule. At $3.6 \mathrm{mg} / \mathrm{m}^{2}$, patients experienced grade 3 diarrhea that resolved at a lower dose level of $2.5 \mathrm{mg} / \mathrm{m}^{2}$. Since diarrhea was prominent at the fourth week of treatment on this schedule, the regimen was modified to 3 -weekly treatments followed by 1 week rest with most patients tolerating $2.5 \mathrm{mg} / \mathrm{m}^{2}$. Dose-limiting toxicity was diarrhea. Other common side effects with this regimen included nausea, vomiting, diarrhea, and fatigue. Few patients experienced grade 3 or 4 myelosuppression (Rubin et al 2005; Schmid et al 2005).

A dose-finding study with dosages ranging 0.3 to $8 \mathrm{mg} / \mathrm{m}^{2}$ every 3 weeks arrived at a dose of $6 \mathrm{mg} / \mathrm{m}^{2}$ for phase II studies. Dose-limiting toxicity was diarrhea at a dosage of $8 \mathrm{mg} / \mathrm{m}^{2}$. Other grade 3 toxicities included fatigue, nausea, and vomiting. Grade 2 peripheral neuropathy was noted in 3 of 42 patients (Calvert et al 2001). Despite doselimiting diarrhea, more studies are ongoing at an increased dosage of 6.5 to $11 \mathrm{mg} / \mathrm{m}^{2}$ for nonsmall cell lung cancer, employing an intensive bowel regimen to prevent diarrhea (Fumoleau et al 2007). Drug disposition is non-renal with no evidence of drug accumulation on repeated dosing. The drug is metabolized by the enzyme carboxylesterse-1 (Rubin et al 2005). 


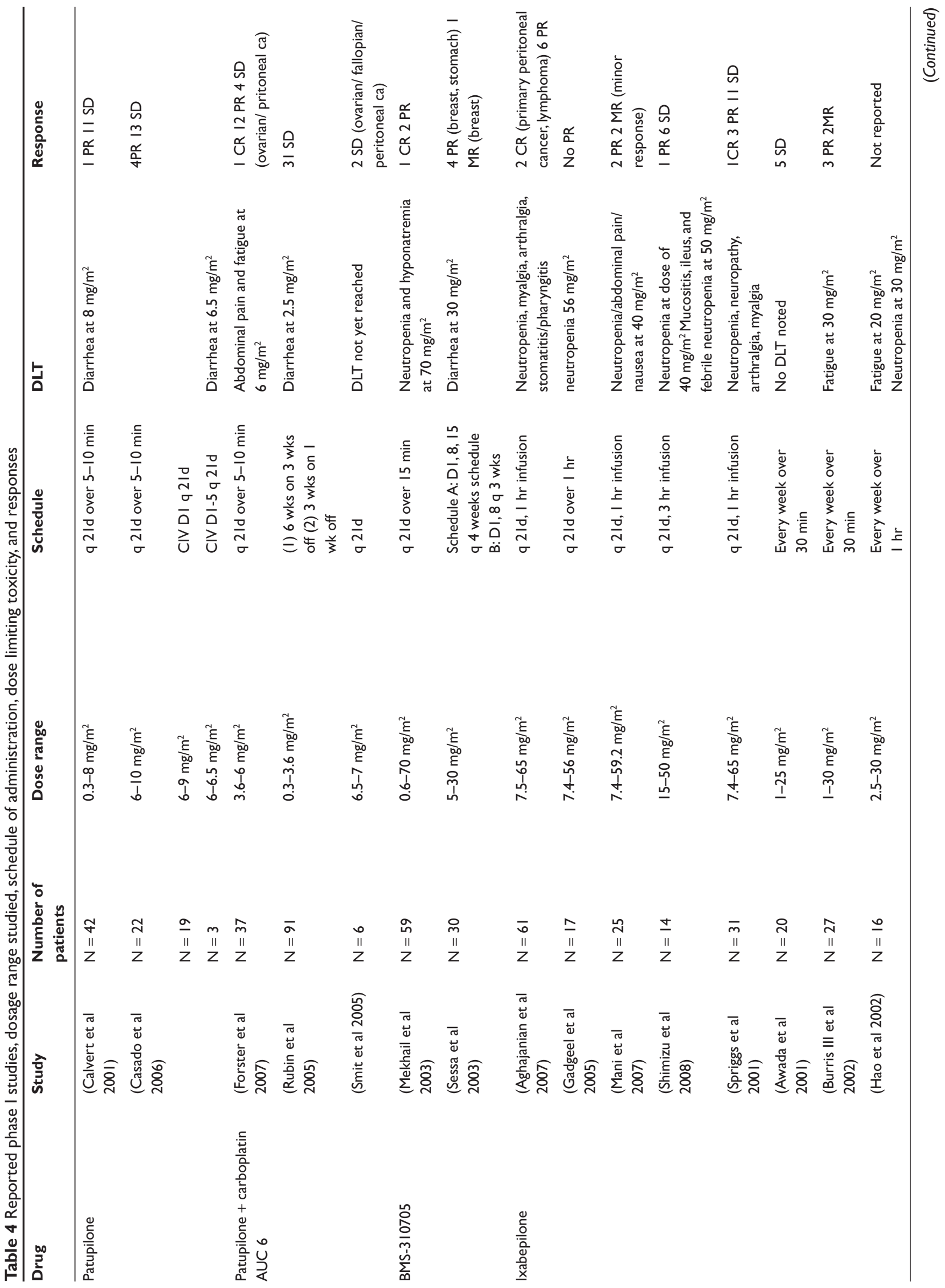




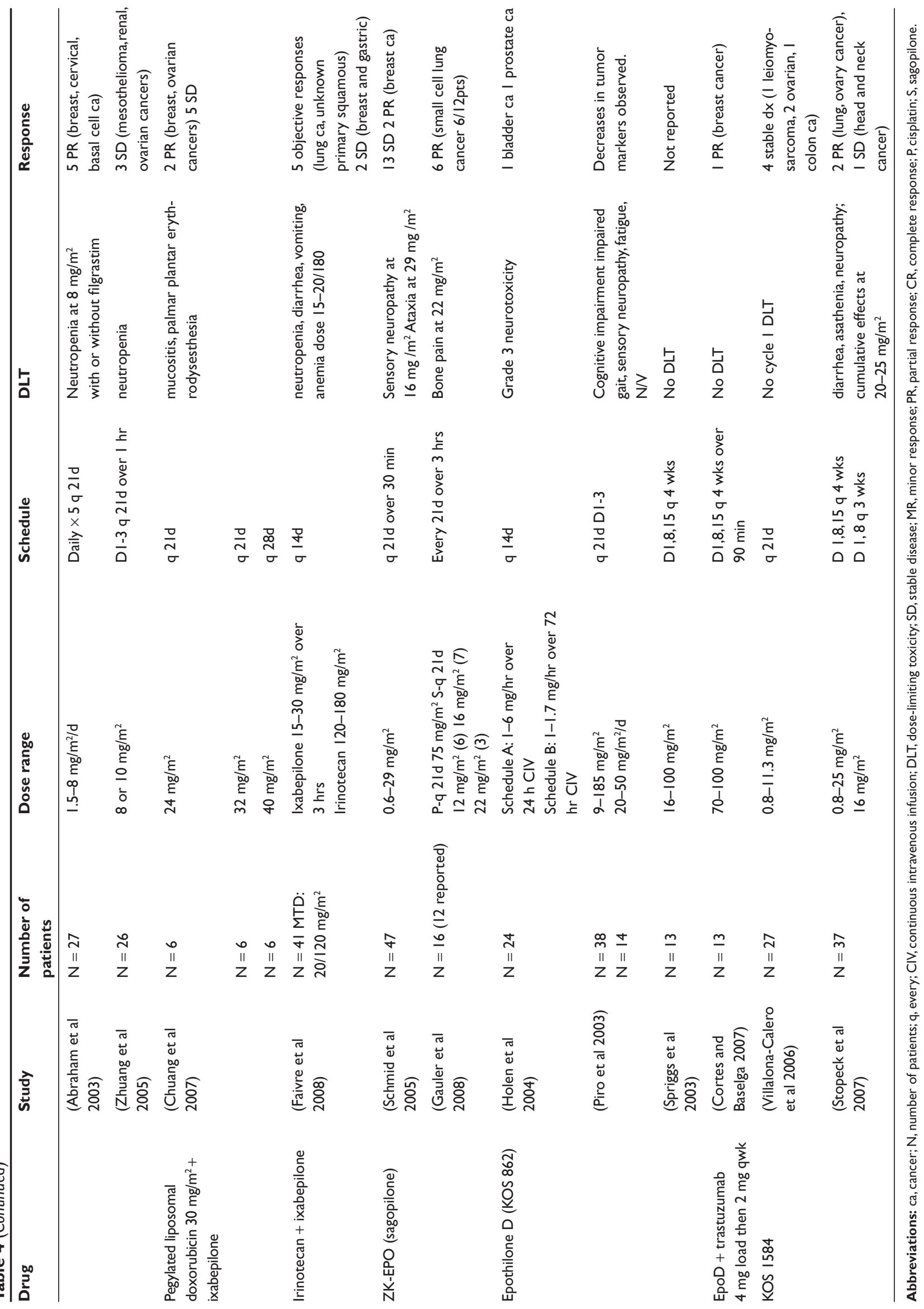




\section{BMS-3 10705}

In contrast to patupilone, this second generation derivative is water soluble (Table 1). The drug has been studied as a 15-minute infusion every 3 weeks, or weekly for 3 weeks (Table 4). No dose limiting toxicity was noted at $40 \mathrm{mg} / \mathrm{m}^{2}$. Dose limiting toxicity of grade 4 hyponatremia secondary to nausea and vomiting, and grade 4 neutropenia occurred at $70 \mathrm{mg} / \mathrm{m}^{2}$. Hypersensitivity reactions were not observed. Common grade 1 side effects included fatigue, alopecia, neuropathy, nausea, constipation, myalgia, chills, and arthralgia. Partial responses to BMS-310705 were seen in one patient with ovarian cancer treated with $40 \mathrm{mg} / \mathrm{m}^{2}$ and one patient with bladder cancer treated with $30 \mathrm{mg} / \mathrm{m}^{2}$ out of a total of 59 patients (Table 4). A complete response was seen in one patient with nonsmall cell lung cancer at a dosage level of $40 \mathrm{mg} / \mathrm{m}^{2}$ (Mekhail et al 2003).

\section{Ixabepilone}

This agent is the most mature epothilone analog in development (Table 4). With the weekly infusions over 30 minutes, there was cumulative sensory neuropathy. Investigators suggested that prolonging infusion time and employing treatment breaks with 3 weeks of treatment followed by 1 week rest may allow patients to better tolerate this agent and continue treatment longer (Burris et al 2002). Heavily pretreated patients were more apt to experience dose-limiting toxicities (Hao et al 2002). Dose ranging studies evaluated prolonged infusion schedules: 7.5 to $65 \mathrm{mg} / \mathrm{m}^{2}$ administered over 1 hour every 3 weeks, and 15 to $50 \mathrm{mg} / \mathrm{m}^{2}$ administered over 3 hours every 3 weeks (Table 4) (Spriggs et al 2001; Aghajanian et al 2007; Shimizu et al 2008).

This agent, dissolved in polyethoxylated caster oil (Cremophor $\mathrm{EL}^{\circledR}{ }^{\circledR}$ ), is associated with a low, but significant risk of hypersensitivity reactions (Aghajanian et al 2007). As a consequence, premedication with antihistamines is required. Some investigators have used corticosteroid prophylaxis in addition (Mani et al 2004; Gadgeel et al 2005; Faivre et al 2008). Corticosteroids may interfere with antitumor effect and are not recommended by the manufacturer, unless significant hypersensitivity reactions are noted. Grade $3-4$ toxicities were initially noted at doses over $40 \mathrm{mg} / \mathrm{m}^{2}$ with the most prominent side effects of neutropenia, myalgia, arthralgia, sensory neuropathy, fatigue, and nausea. The maximum tolerated dose was determined to be $50 \mathrm{mg} / \mathrm{m}^{2}$ every 3 weeks. Some patients who had experienced sensory neuropathy recovered to baseline or to less than grade 1 usually after 2 cycles of treatment (Mani et al 2004). Grade 3-4 neuropathy occurred in $7 \%$ to $19 \%$ of patients receiving $40 \mathrm{mg} / \mathrm{m}^{2}$ every 3 weeks while those receiving daily ixabepilone for 3 or 5 days had grade 3 neurotoxicity of $0 \%$ to $3 \%$. With this schedule change that decreased severe neuropathy, more patients experienced significant diarrhea. Other grade 3 nonhematologic toxic effects included fatigue, anorexia, and stomatitis. Peripheral neuropathy was mild (Abraham et al 2003; Zhuang et al 2005). Although no formal study has been reported in patients with hepatic compromise, the manufacturer advises caution when using this agent in such patients. This recommendation is based on the known metabolism of these agents as previously discussed. Ixabepilone has been studied by the oral route in a phase I-II trial but no data have been presented to date.

Ixabepilone has been combined with liposomal doxorubicin and also with irinotecan with responses noted in heavily treated patients (Table 4). Toxicities reflected the agents administered. Additional combination studies are ongoing and listed by http://clinicaltrials.gov, but not reported in abstract or in manuscript form at this time.

\section{Epothilone D}

A murine model suggested that optimal administration of this agent would occur with prolonged infusion (Holen et al 2004). Therefore, prolonged infusion times of 24 and 72 hours administration were evaluated (Table 4). Because of a rapid alpha distribution of epothilone D suggesting rapid tissue uptake, loading doses of the drug were given to maintain a steady state plasma drug concentration. Grade 3 neurotoxicity was reported at $6 \mathrm{mg}$ /hour in the 24-hour continuous infusion cohort. Other observed adverse effects included fatigue, nausea, abdominal pain, and dizziness. One patient with bladder cancer had a decrease of primary nodal metastasis, and 1 patient with prostate cancer experienced a $25 \%$ decline of plasma prostate specific antigen (Table 4) (Holen et al 2004). Other schedules studied included once every 3 weeks and day 1-3 consecutive dosing. Neurological toxicity occurred more frequently in patients who received a large single dose of $150 \mathrm{mg} / \mathrm{m}^{2}$ compared with patients who received a daily schedule for 3 days. Neurotoxicity was most apt to be seen 1 to 2 days postinfusion and resolved in 2 to 7 days. This toxicity did not seem to be cumulative in these early trials. Mild neutropenia and anemia also occurred (Piro et al 2003). Another schedule evaluated was 16 to $100 \mathrm{mg} / \mathrm{m}^{2}$ given day $1,8,15$ every 4 weeks. Toxicities were reported as mild to moderate, including fatigue, nausea and vomiting, and sensory neuropathy (Spriggs et al 2003). Interest in this drug has diminished as the newer analog KOS-1584 is 
a more attractive compound based on its water solubility and preclinical activity.

\section{KOS-I584}

Dose-ranging studies of 0.8 to $11.3 \mathrm{mg} / \mathrm{m}^{2}$ administered over 3 hours every 3 weeks were performed in 27 patients with solid tumors (Table 4) (Villalona-Calero et al 2006). Another study evaluated dosages of 0.8 to $25 \mathrm{mg} / \mathrm{m}^{2}$ given days 1,8 , 15 every 4 weeks (Stopeck et al 2006). Studies reported side effects that were not dose dependent and included diarrhea, constipation, nausea, fatigue, and elevated aspartate transaminases. Neurotoxicity was not significant. Stable disease was noted in some patients enrolled in the phase I trial. Dose related increases in polymerized microtubules in peripheral blood mononuclear cells were observed. The percentage of polymerized microtubules ranged from $20 \%$ at a dose of $0.8 \mathrm{mg} / \mathrm{m}^{2}$ to $40 \%$ to $50 \%$ at a dose of $8.5 \mathrm{mg} / \mathrm{m}^{2}$. Of note, at a dose of $5 \mathrm{mg} / \mathrm{m}^{2}$ the amount of polymerized microtubules reached $48 \%$, suggesting that a plateau of polymerization effect occurs at clinical dosages (Stopeck et al 2006).

\section{Sagopilone}

This analog is a fully synthetic epothilone and is not a substrate for P-glycoprotein (Hoffmann et al 2008). Information about this agent remains sparse although http:// clinicaltrials.gov lists several trials. A dose ranging study of 0.6 to $29 \mathrm{mg} / \mathrm{m}^{2}$ administered over 30 minutes every 3 weeks demonstrated dose-limiting toxicity: ataxia at $16 \mathrm{mg} / \mathrm{m}^{2}$, and neuropathy at $29 \mathrm{mg} / \mathrm{m}^{2}$. Partial responses were seen in extensive small cell lung cancer and in 2 patients with breast cancer previously treated with a taxane (Table 4) (Schmid et al 2005; Gauler et al 2008).

\section{Phase II data}

The available phase II data are summarized by tumor type in Table 5. The largest number of trials reported involved the administration of ixabepilone either as a single agent or in combination with other established agents.

Ixabepilone has been widely studied for metastatic breast cancer with or without prior taxane exposure using a variety of schedules (Table 5). The response rates for patients without prior taxane exposure range from $41.5 \%$ to $57 \%$ (Denduluri et al 2007; Roche et al 2007). The response rates were lower for relapsed or refractory patients who had failed to respond to taxane treatment (11.5\% to $22 \%$ ) (Low et al 2005; Perez et al 2007; Thomas et al 2007a).

Response rates increased in the taxane resistant patients with the addition of capecitabine to ixabepilone, or the addition of trastuzumab with ixabepilone for Her2+ breast cancer patients (Moulder et al 2007; Thomas et al 2007b). These studies suggest that this agent can be combined with known effective drugs commonly used with taxane therapy.

One single arm phase II trial, initially presented in abstract form (Perez et al 2007), has led to US Food and Drug Administration (FDA) approval for commercial use in heavily treated breast cancer patients who had failed to respond to anthracyclines, taxanes, and capecitabine (Lechleider et al 2008). In the updated report, 126 patients from 36 centers with prior drug resistance, and at least one evaluable lesion by imaging, Karnofsky performance status $\geq 70$, and normal organ function were treated with ixabepilone at $40 \mathrm{mg} / \mathrm{m}^{2}$ administered as an intravenous infusion once every 3 weeks. Independent review committee response evaluation of the 113 study patients determined a $12.4 \%$ partial response rate with a median time to response of 6.1 weeks and an average duration of response of 6 months (5 to 7.6 months, 95\% confidence limits) (Lechleider et al 2008).

One ongoing study is evaluating epothilone B in the setting of metastatic breast cancer patients with brain metastases, progressing after whole brain radiation therapy, with 1 out of 12 patients demonstrating a partial response (Conlin et al 2008). The grade 3-4 toxicities reported were mainly gastrointestinal.

Patupilone has been evaluated in patients with metastatic carcinoid and related neuro-endocrine tumors (Table 5). Preliminary data demonstrate disease stabilization with grade 3-4 gastrointestinal side effects (Anthony et al 2003).

Advanced colon cancer patients refractory to at least one prior chemotherapy containing 5-fluorouracil, irinotecan, and leucovorin (IFL) did not respond to ixabepilone (Eng et al 2004). Patupilone treatment in 47 patients with colon cancer on a once weekly for three weeks schedule every 28 days noted only 1 partial response but was associated with significant toxicity (Table 5) (Poplin et al 2003).

A study of metastatic gastric cancer patients treated with ixabepilone at $50 \mathrm{mg} / \mathrm{m}^{2}$ administered once every 21 days resulted in a $9 \%$ response rate ( 2 out of 23 patients) (Ajani et al 2006). No response was seen in patients who received ixabepilone $6 \mathrm{mg} / \mathrm{m}^{2}$ for 5 days, possibly related to low plasma drug concentrations with this divided dosing schedule. Grade 3 to 4 neuropathies in the $50 \mathrm{mg} / \mathrm{m}^{2}$ cohort and $6 \mathrm{mg} / \mathrm{m}^{2}$ cohort were statistically different ( $8 \% \mathrm{vs} 4 \%$ ) (Ajani et al 2006). In another study of locally advanced or metastatic gastric cancer patients, patupilone demonstrated a partial response rate of $9 \%$ of patients and a combined 


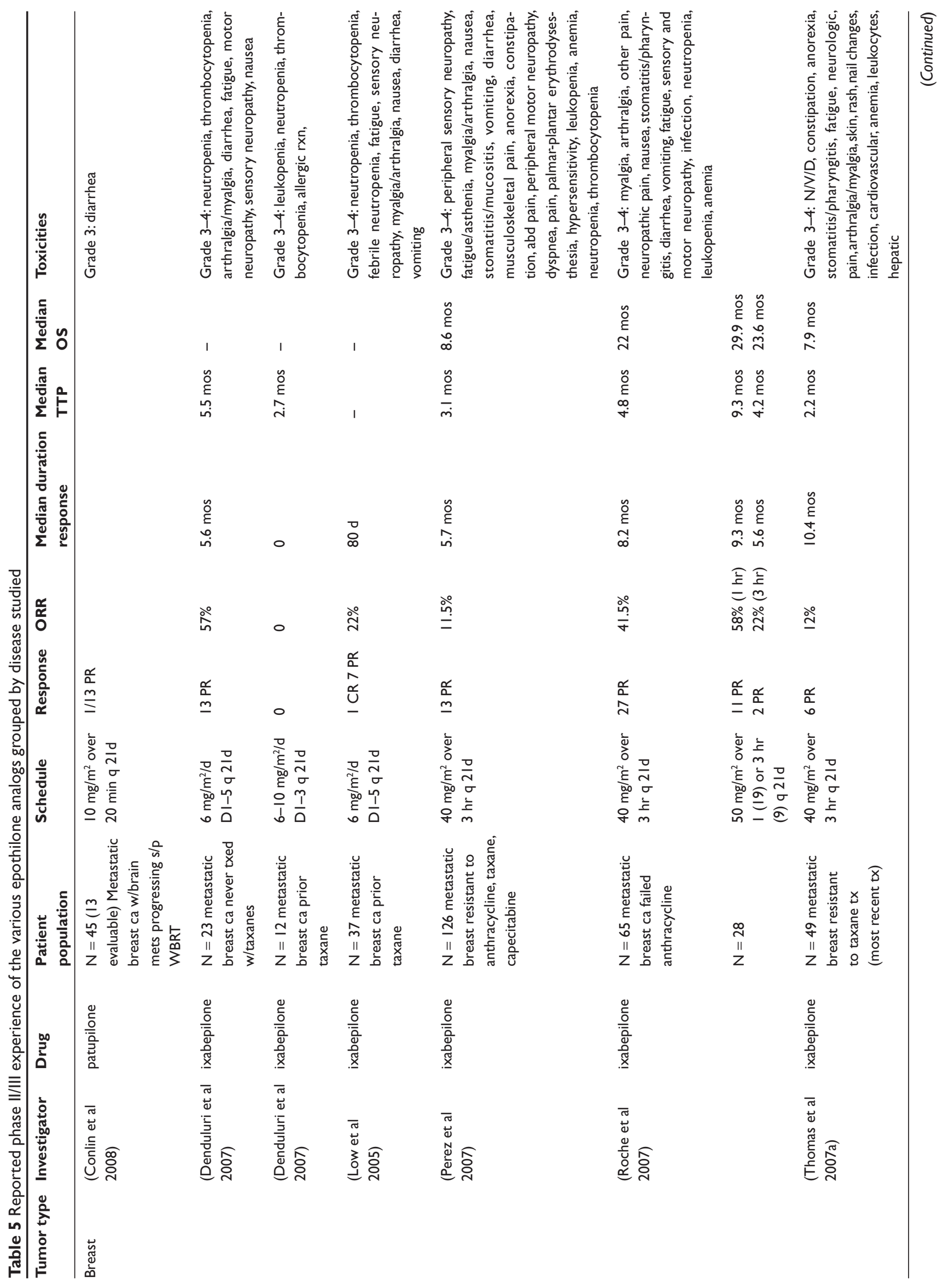








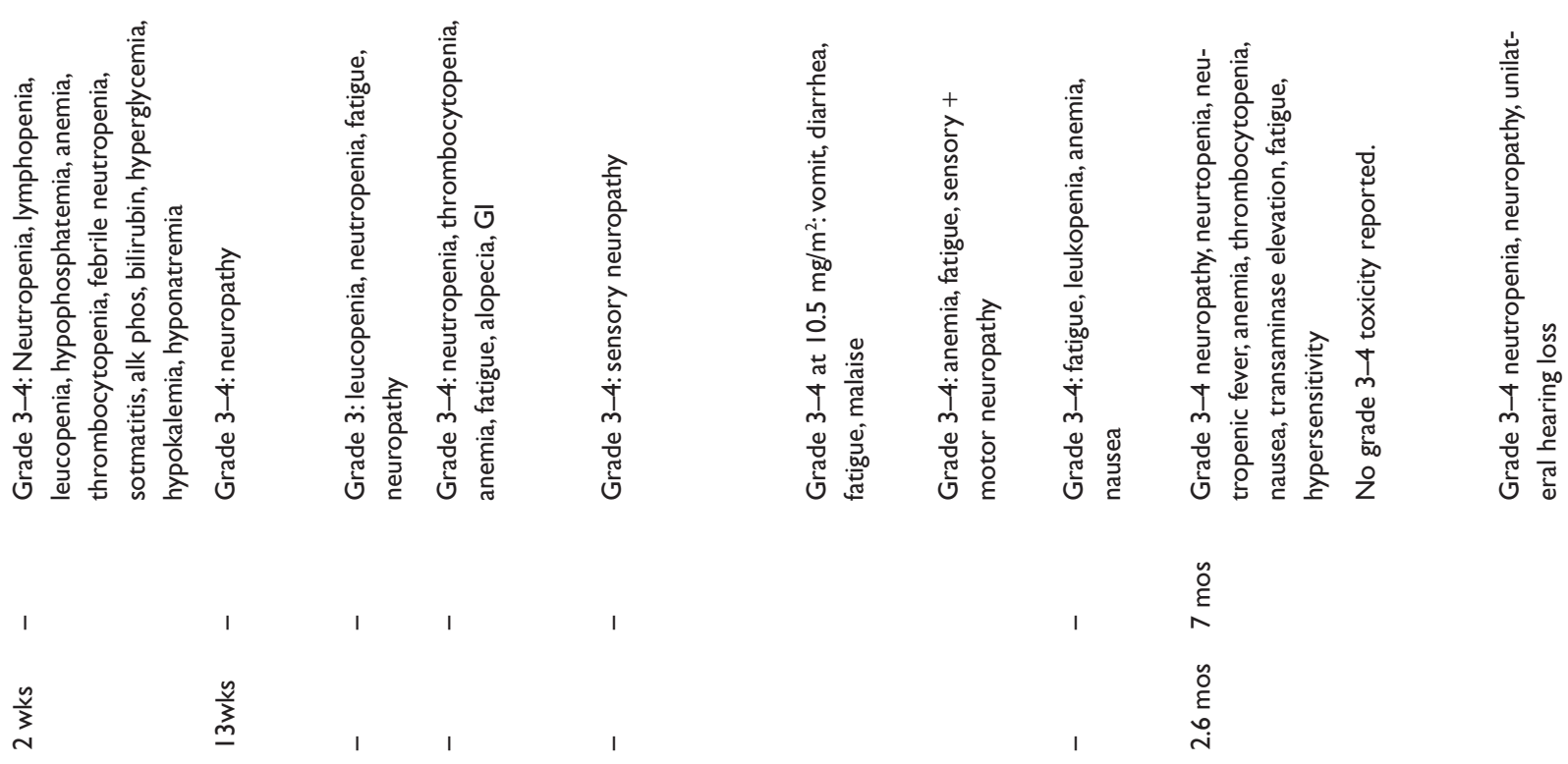

矛

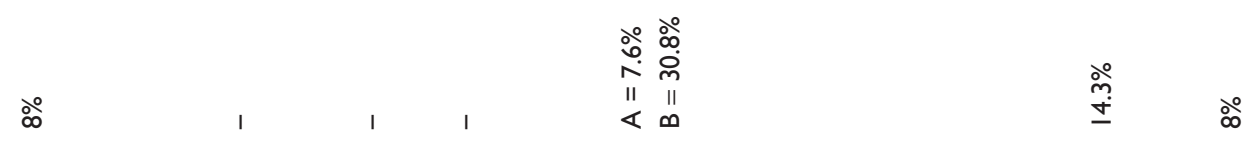

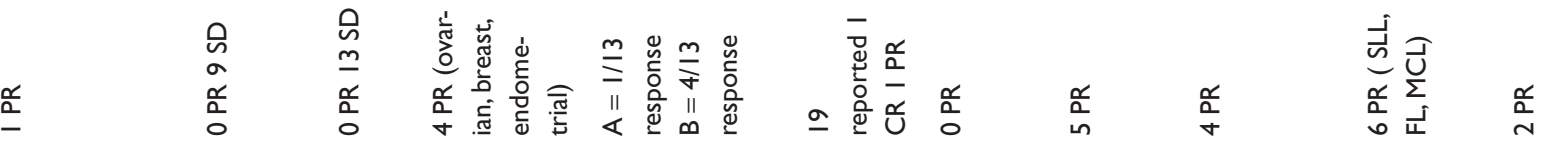

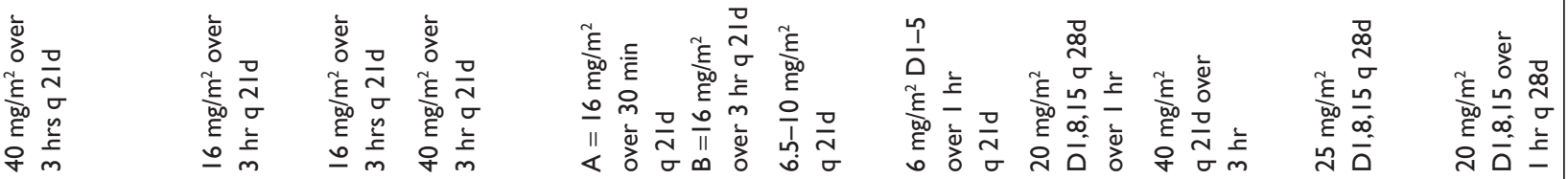
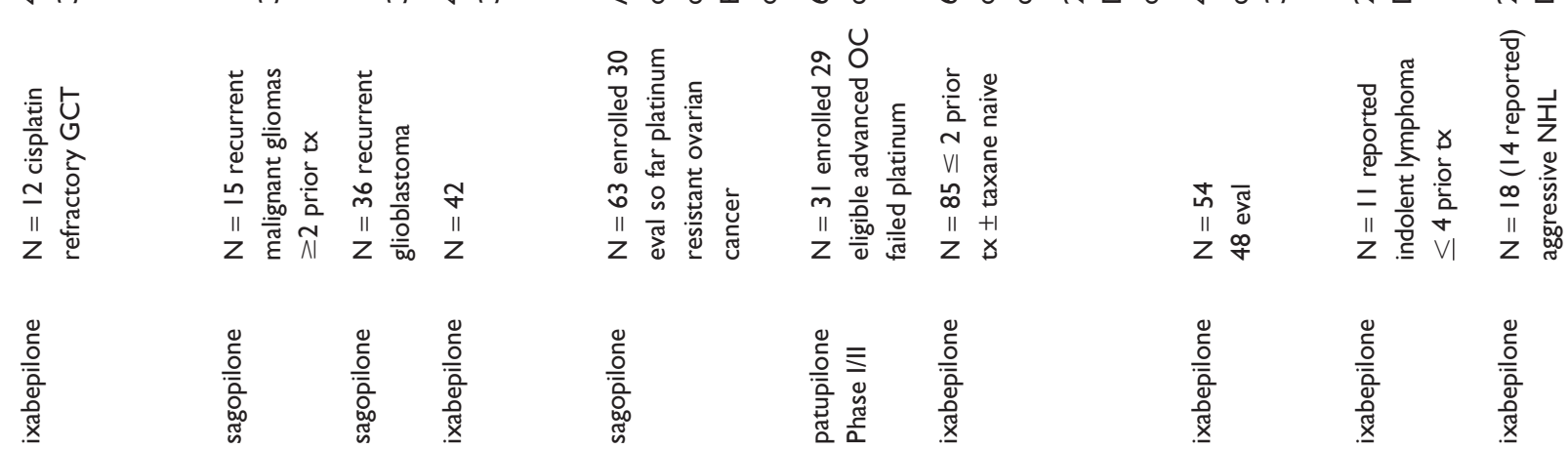

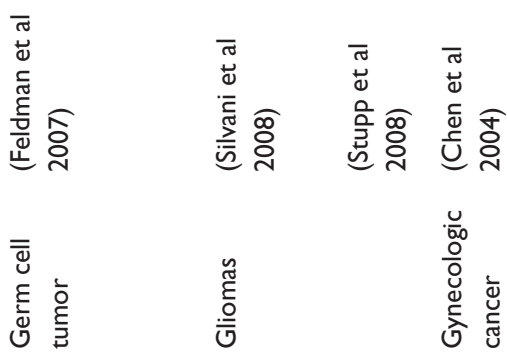

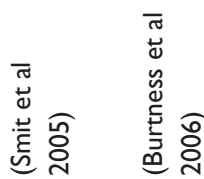

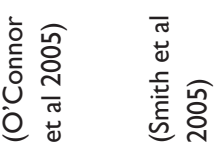
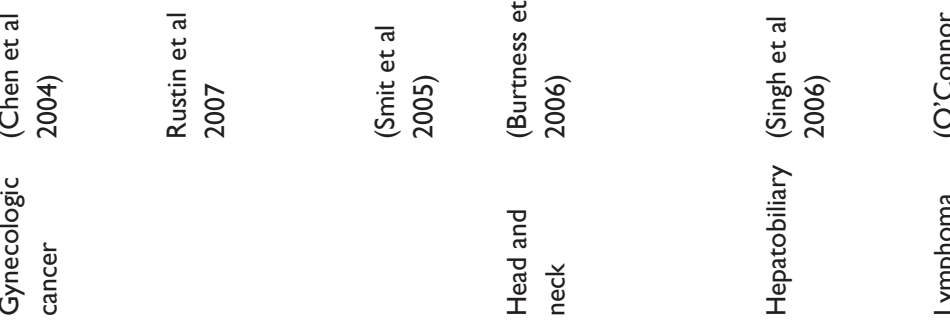


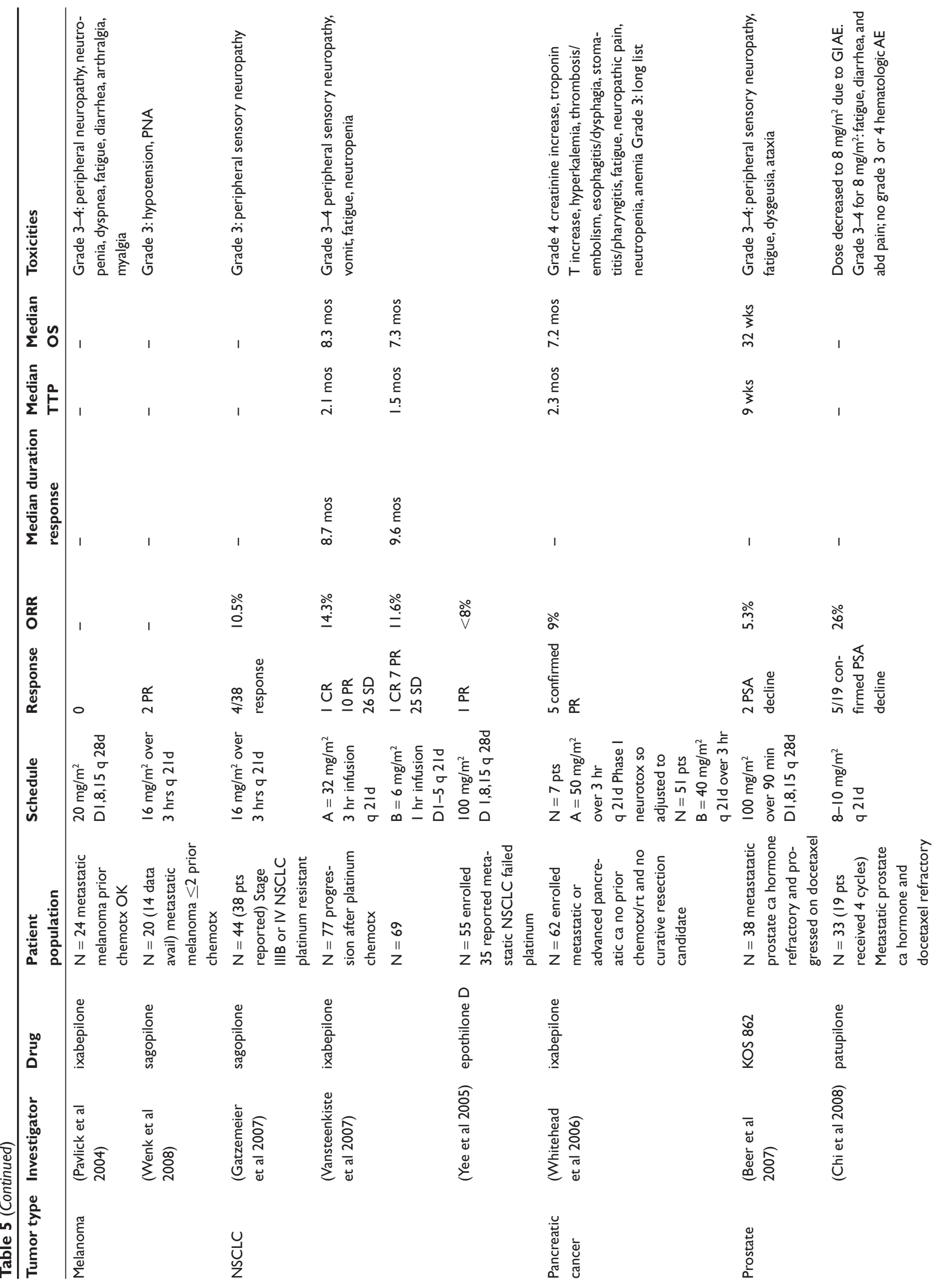






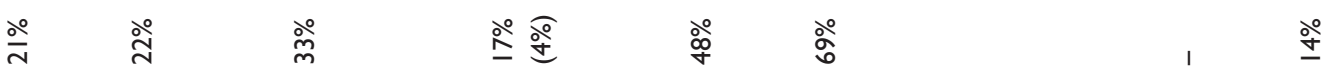

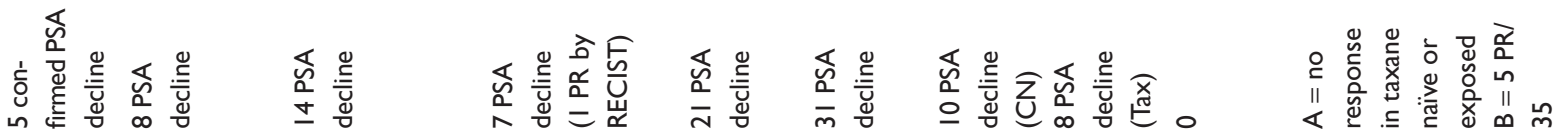

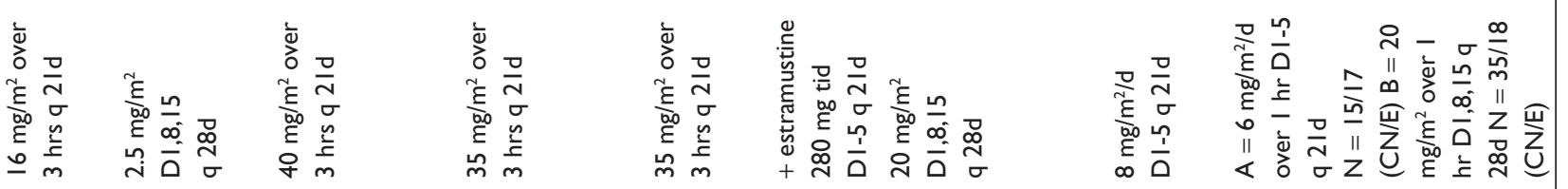

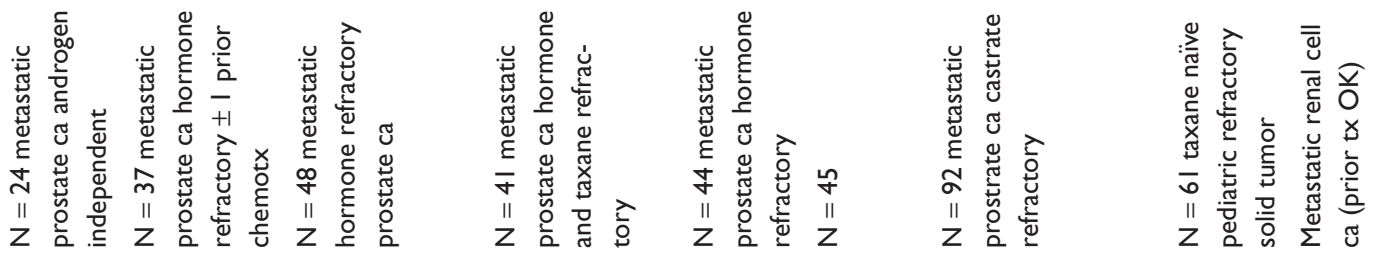

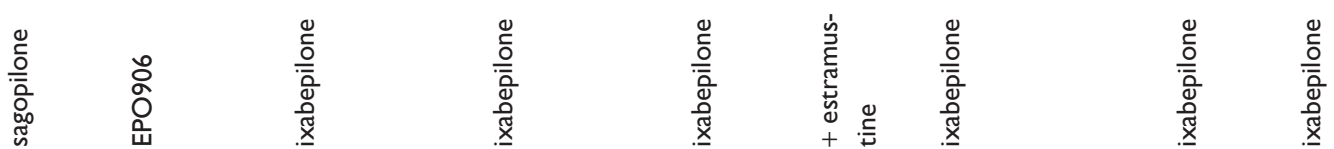

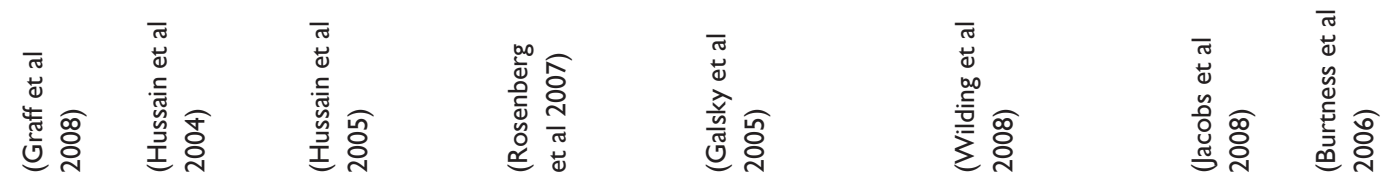

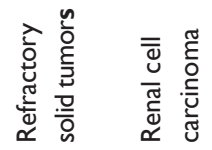




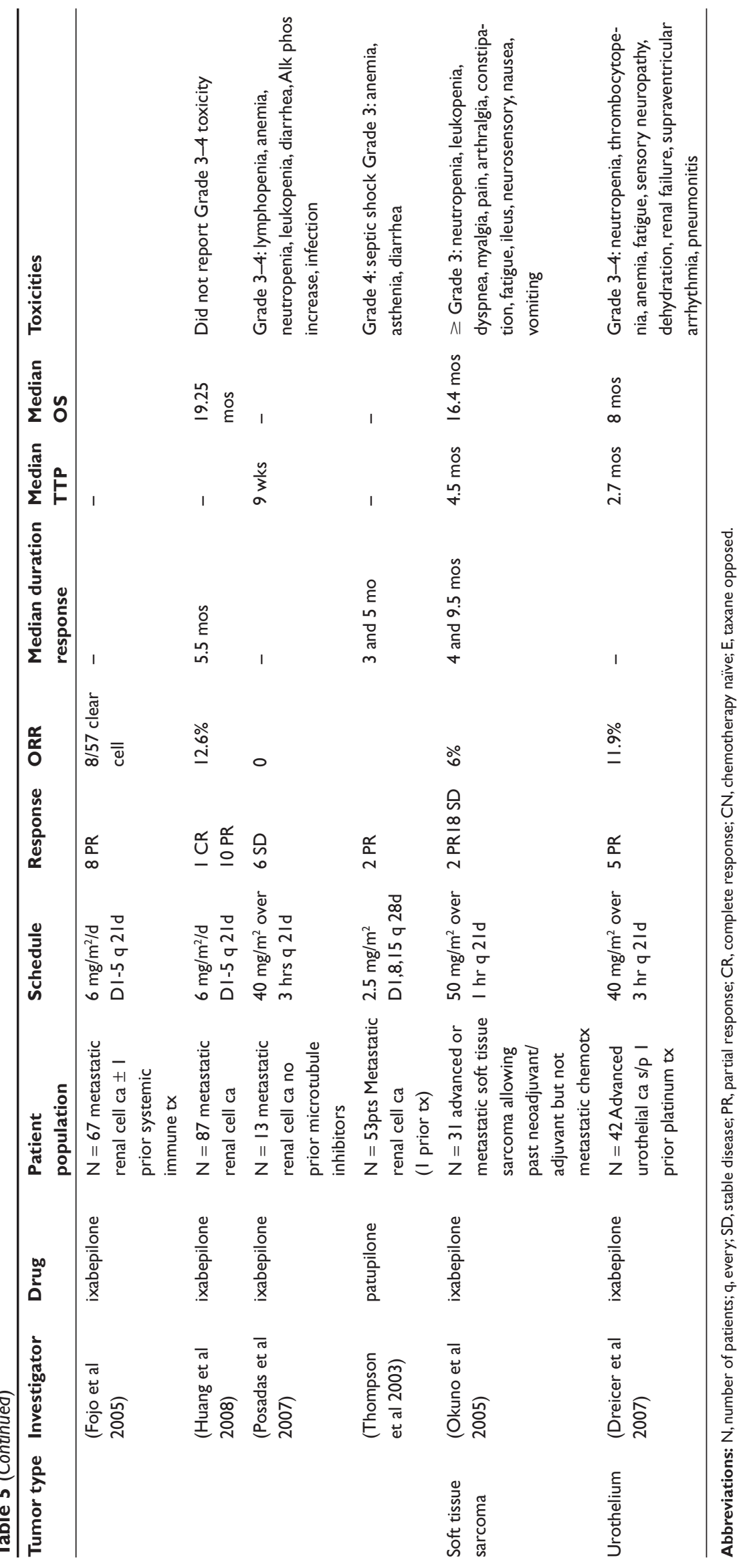


response and disease stabilization rate of $36 \%$ (Hsin et al 2006).

Ixabepilone was evaluated in hepatobiliary cancer and while there were partial responses and disease stabilization, the magnitude of the anticancer effects was deemed to be not clinically significant (Singh et al 2006).

Ixabepilone has been a disappointment in metastatic germ cell tumors refractory to cisplatin therapy. Only 12 patients were entered into the study with 1 partial response in a taxane naive patient. The time to progression was 2 weeks, and the study was terminated (Table 5) (Feldman et al 2007).

Sagopilone was believed to be a good candidate for evaluation in human brain tumors based upon preclinical data and absence of perturbation of in vitro efficacy by the P-glycoprotein resistance protein (Alexander et al 2008; Hoffmann et al 2008). However, in phase II trials for recurrent malignant gliomas and recurrent glioblastomas, this agent demonstrated disease stability of only 6 to 13 weeks duration (Table 5) (Silvani et al 2008; Stupp et al 2008).

For gynecologic cancers, preliminary data in patients with advanced ovarian cancer who did not respond to prior platinum drugs demonstrated a $10 \%$ response rate (Smit et al 2005). Ixabepilone has also shown responses in ovarian and endometrial cancer patients previously treated with taxanes (Table 5) (Chen et al 2004).

In head and neck cancer, ixabepilone was studied in two regimens: 1) treatment on days 1 to 5 repeated every 21 days, or 2) weekly dosing. Burtness et al (2006) also stratified patients with metastatic or recurrent squamous cell cancer of the head and neck on the basis of being taxane naïve or having prior taxane exposure. Partial responses were seen in the taxane-naïve patient group using the weekly regimen (Table 5). Lower rates of sensory and motor neuropathy were noted in the 5-day dosing regimen compared with the weekly regimen in both taxane-naïve and exposed groups (Burtness et al 2006).

Preliminary data show activity of ixabepilone in indolent, mantle cell lymphoma, and aggressive non-Hodgkin's lymphoma (O'Connor et al 2005; Smith et al 2005). Ixabepilone is not an effective treatment in Stage IV melanoma while sagopilone demonstrated responses in 2 out of 14 patients who had previously failed dacarbazine or temozolamide (Pavlick et al 2004; Wenk et al 2008). Ixabepilone and KOS-862 have shown responses in non-small cell lung cancer that failed prior platinum (Yee et al 2005; Vansteenkiste et al 2007). Ixabepilone did not show significant responses in children and adults with refractory pediatric tumors
(Jacobs et al 2008). Ixabepilone has also been noted to have activity in soft tissue sarcoma (Okuno et al 2005).

In patients with prostate cancer that was castrate resistant and taxane refractory, patupilone, ixabepilone, and KOS-862 have all decreased prostate specific antigen levels (Beer et al 2007; Rosenberg et al 2007; Chi et al 2008). In patients with castrate refractory metastatic prostate cancer tumors, but not chemotherapy-resistant tumors, patupilone, ixabepilone, and sagopilone induced prostate-specific antigen declines (Hussain et al 2004, 2005; Graff et al 2008).Ixabepilone has been studied in different dosing regimens with the once every 21 days dosing schedule compared with days 1, 8, 15 dosing every 28 days. Higher rates of grade 3-4 sensory neuropathy and neutropenia occurred in the days $1,8,15$ regimen (Hussain et al 2005; Wilding et al 2008). The addition of estramustine to ixabepilone increased the response rate compared with ixabepilone alone (response rate $69 \%$ vs $48 \%$ respectively) (Galsky et al 2005).

Unlike most ixabepilone dosing regimens demonstrating better responses with the once every 21 day regimen, metastatic renal cell carcinoma treated with this schedule had stable disease as the best response (Posadas et al 2007). In this tumor, ixabepilone was administered on days 1 to 5 every 21 days or on days $1,8,15$ with a cycle length of 28 days. Both regimens demonstrated responses (Fojo et al 2005; Burtness et al 2006; Huang et al 2008). Patupilone has also been shown to have activity in metastatic renal cell carcinoma (Thompson et al 2003). Ixabepilone also has activity in advanced urothelial cancer (Dreicer et al 2007).

\section{Phase III trials}

Only one completed open label phase III trial has been presented and published at the time of this review. This study was a multi-institution collaboration involving 160 multinational sites. Ixabepilone combined with capecitabine was compared with capecitabine alone in a cohort of female patients with metastatic or locally advanced breast cancer, previously exposed to taxanes and anthracyclines (Thomas et al 2007b). Patients who had progression of their tumor during treatment, or within 3 months of prior treatment, or had a recurrence of their tumor within 6 months of adjuvant or neo-adjuvant treatment after exposure to anthracyclines and taxanes were eligible. The entry criteria were modified after 377 patients were enrolled to allow progression within 4 months of treatment or within 12 months of adjuvant/neoadjuvant therapy. Patients with known brain metastasis, end organ dysfunction, or National Cancer Institute CTC 
criteria of neuropathy $\geq$ grade 2 were excluded. Further exclusions included hypersensitivity to the study drugs, use of cytochrome P450 3A4 inhibitors, and known or suspected dihydropyrimidine dehydrogenase (involved in fluorouracil metabolism) deficiency. Ixabepilone was administered as an intravenous infusion at $40 \mathrm{mg} / \mathrm{m}^{2}$ over 3 hours every 21 days. In the combination arm, capecitabine was administered orally at $2000 \mathrm{mg} / \mathrm{m}^{2}$ in 2 divided daily doses for 14 days every 21 days or in the single agent comparator arm capecitabine at $2500 \mathrm{mg} / \mathrm{m}^{2}$ in 2 divided daily doses for 14 days on a 21 day cycle (Thomas et al 2007b).

The median age of study patients was 53 with a range of 25 to 79 years. Approximately two-thirds were hormone receptor positive, $15 \%$ of patients had Her2 positive tumors, $84 \%$ had visceral disease, and $92 \%$ of patients received protocol therapy as second or third line treatment for metastatic disease. The combination demonstrated a superior progression-free survival (hazard rate 0.75 , $\mathrm{p}=0.003$ ) of 5.8 months compared with 4.2 months for capecitabine alone. Independent review of responses noted $35 \%$ of patients achieved response in the combination arm vs $14 \%$ of patients in the monotherapy arm ( $p<0.0001)$. Peripheral neuropathy was noted in $65 \%$ of patients in the combination arm with grade 3 neuropathy in $20 \%$ and grade 4 in $1 \%$. Of the patients receiving the combination arm, $21 \%$ discontinued therapy after a median of 6 cycles due to grade 3-4 peripheral neuropathy. Myelosuppression was also noted in the ixabepilone arm with a $5 \%$ incidence of febrile neutropenia (Thomas et al 2007b). Twenty percent of patients on the combination arm required growth factor support. An updated report of this study with a reanalysis of the progression-free survival indicated the median progression free survival in the combination arm was 5.7 months compared with 4.1 months in the monotherapy arm (Thomas 2008). On the basis of this trial, ixabepilone was approved by the FDA for commercial use in the US (Lechleider et al 2008).

\section{Conclusions}

Epothilones have potent preclinical and clinical activity in human malignancies. As such, they represent new entities that need to be integrated into cancer treatment. Early studies indicate that drugs of this class have broad activity in many of the human tumor types. These agents have a preclinical rationale to offer an advance over taxane therapy and in early human phase I-II trials have noted responses in patients believed to be taxane resistant. However, their distinction from the more commonly used taxane drugs in the treatment of clinical disease will require a randomized phase III trial of an epothilone vs. taxane as primary therapy for metastatic disease. No such trial has been reported. This concern is not a trivial issue as the US Medicare reimbursement for a single treatment with paclitaxel at $175 \mathrm{mg} / \mathrm{m}^{2}$ for a patient of $1.7 \mathrm{~m}^{2}$ is US $\$ 570$ per treatment and for ixabepilone at $40 \mathrm{mg} / \mathrm{m}^{2}$ for the same patient is US\$17,615.

The role of $\mathrm{P}$-glycoprotein resistance protein as a primary mechanism of clinical refractoriness of tumors to anticancer therapy is a controversial area. The major difference between epothilones and taxanes is the ability of epothilones to be unaffected by the P-glycoprotein resistance pump. As previously mentioned, specific subgroups of solid tumors such as the Her 2 positive breast cancers may be a particularly important target for this class of agents. Other mechanisms of resistance are also thought to be important in the management of solid tumors.

The epothilones such as ixabepilone and sagopilone, analogous to taxanes, exhibit neurologic toxicity. Although changes in the dosing schedule, decreasing the maximum plasma concentration, and prolonging infusion to lessen $\mathrm{C}_{\mathrm{p}}$ max may diminish neurological adverse effects, such treatments have shifted the dose limiting toxicity from neurological to gastrointestinal adverse events. These toxicities in part may reflect the heavily pretreated population exposed in the initial studies to these agents. Data on the efficacy and toxicity of the various epothilone analogs as primary therapy in humans is urgently needed as the toxicities in this group of patients may be markedly less.

The epothilone structure does allow semisynthetic and fully synthetic production of the agent. In addition, the chemical structure is more amenable to modification than is paclitaxel. As a consequence, there are a plethora of analogs which are undergoing evaluation (Altmann and Memmert 2008). The ability to modify the chemical structure also allows the solubility and stability of the agent to be adjusted for human use. In addition, the structure allows modifications that significantly differ from the parent compound and yet allow the resulting compounds to remain tubulin binders (Feyen et al 2008). At present, epothilone D is not being actively clinically investigated.

Ixabepilone is the most clinically developed of the analogs and has received commercial approval in the US for treatment of refractory breast cancer. This approval is on the basis of efficacy in clinically taxane resistant breast cancer as a single agent and in combination with capecitabine. Combination of epothilones with either classical cytotoxics or with biologics 
are currently in progress and will serve to further define the role of these drugs in the treatment of cancer.

\section{Disclosures}

None of the authors have any conflicts of interest to disclose.

\section{References}

Abraham J, Agrawal M, Bakke S, et al. 2003. Phase I trial and pharmacokinetic study of BMS-247550, an epothilone B analog, administered intravenously on a daily schedule for five days. J Clin Oncol, 21:1866-73.

Aghajanian C, Burris HA 3rd, Jones S, et al. 2007. Phase I study of the novel epothilone analog ixabepilone (BMS-247550) in patients with advanced solid tumors and lymphomas. J Clin Oncol, 25:1082-8.

Ajani JA, Safran H, Bokemeyer C, et al. 2006. A multi-center phase II study of BMS-247550 (Ixabepilone) by two schedules in patients with metastatic gastric adenocarcinoma previously treated with a taxane. Invest New Drugs, 24:441-6.

Alexander E, Rosa E, Bolos J, et al. 2008. Sagopilone. Drugs Future, 33:496-505.

Altmann K-H. 2005. Recent developments in the chemical biology of epothilones. Current Pharm Design, 11:1595-613.

Altmann K-H, Memmert K. 2008. Epothilones as lead structures for new anticancer drugs - pharmacology, fermentation, and structure-activityrelationships. Prog Drug Res, 66:275-334.

Altmann KH, Florsheimer A, O'Reilly T, et al. 2004. The natural products epothilones A and B as lead structures for anticancer drug discovery: chemistry, biology, and SAR studies. Prog Med Chem, 42:171-205.

Anthony L, Carlisle T, Pommier R, et al. 2003. An open-label phase IIA trial evaluating the safety and efficacy of EPO906 as therapy in patients with metastatic carcinoid and other neuroendocrine tumors. Proc Am Soc Clin Oncol, 22:1413a.

Awada A, Bleiber H, de Valeriola D, et al. 2001. Phase I clinical and pharmacology study of the epothilone analog BMS-247550 given weekly in patients (pts) with advanced solid tumors. Proc Am Soc Clin Oncol, 20:427a.

Beer TM, Higano CS, Saleh M, et al. 2007. Phase II study of KOS-862 in patients with metastatic androgen independent prostate cancer previously treated with docetaxel. Invest New Drugs, 25:565-70.

Berrieman HK, Lind MJ, Cawkwell L. 2004. Do beta-tubulin mutations have a role in resistance to chemotherapy? Lancet Oncol, 5:158-64.

Beumer JH, Garner RC, Cohen MB, et al. 2007. Human mass balance study of the novel anticancer agent ixabepilone using accelerator mass spectrometry. Invest New Drugs, 25:327-34.

Bhat KM and Setaluri V. 2007. Microtubule-associated proteins as targets in cancer chemotherapy. Clin Cancer Res, 13:2849-54.

Bijman M, Amerongen G, Laurens N, et al. 2006. Microtubule-targeting agents inhibit angiogenesis at subtoxic concentrations, a process associated with inhibition of rac1 and cdc42 activity and changes in the endothelial cytoskeleton. Mol Cancer Ther, 5:2348-57.

Bollag DM, McQueney PA, Zhu J, et al. 1995. Epothilones, a new class of microtubule-stabilizing agents with a taxol-like mechanism of action. Cancer Res, 55:2325-33.

Budman DR. 2005. Therapeutic index, tubulin binders, and clinical medicine. Cancer Invest, 23:479-80.

Burris H. 2007. In Chemotherapy Foundation Symposium Clinical update on 2nd generation epothilone KOS-158. [online]. URL: www. chemotherapyfoundationsymposium.org.meeting.

Burris III H, Awada A, Jones S, et al. 2002. Phase I study of the novel epothilone BMS-247550 administered weekly in patients (pts) with advanced malignancies. Proc Am Soc Clin Oncol, 21:412a.

Burtness B, Goldwasser M, Axelrod R, et al. 2006. A randomized phase II study of BMS-247550 (ixabepilone) given daily $\times 5$ days every 3 weeks or weekly in patients with metastatic or recurrent squamous cell cancer of the head and neck. Proc Am Soc Clin Oncol, 24:5532a.
Calvert P, O’Neill V, Twelves C, et al. 2001. A phase I clinical and pharmacokinetic study of EPO906 (epothilone B), given every three weeks, in patients with advanced solid tumors. Proc Am Soc Clin Oncol, 20:429a.

Casado E, Tabernero J, Melicher B, et al. 2006. Patupilone in chemotherapypretreated patients with advanced colorectal cancer receiving nutritional support and intensive diarrhea management. A phase I multicenter trial. Proc Am Soc Clin Oncol, 24:3593a.

Chen JG and Horwitz SB. 2002. Differential mitotic responses to microtubulestabilizing and -destabilizing drugs. Cancer Res, 62:1935-8.

Chen T, Molina A, Moore S, et al. 2004. Epothilone B analog (BMS247550) at the recommended phase II dose (RPTD) in patients (pts) with gynecologic (gyn) and breast cancers. Proc Am Soc Clin Oncol, 22:2115a.

Chi K, Beardsley E, Venner P, et al. 2008. A phase II study of patupilone in patients with metastatic hormone refractory prostate cancer (HRPC) who have progressed after docetaxel. Proc Am Soc Clin Oncol, 26:5166a.

Chou TC, Zhang XG, Harris CR, et al. 1998. Desoxyepothilone B is curative against human tumor xenografts that are refractory to paclitaxel. Proc Natl Acad Sci U S A, 95:15798-802.

Chuang E, Vahdat L, Caputo T, et al. 2007. Phase I clinical trial of ixabepilone and pegylated liposomal doxorubicin in patients with advanced breast or ovarian cnacers: New York Consortium Trial P7229. Proc Am Soc Clin Oncol, 25:2570a.

Conlin A, D'Andrea G, Hudis C, et al. 2008. Phase II trial of patupilone in patients (pts) with breast cancer brain metastases (BCBM) progressing or recurring after whole brain radiation therapy (WBXRT). Proc Am Soc Clin Oncol, 26:1086a.

Cortes J, Baselga J. 2007. Targeting the microtubules in breast cancer beyond taxanes:the epothilones. Oncologist, 12:271-80.

Denduluri N, Low JA, Lee JJ, et al. 2007. Phase II trial of ixabepilone, an epothilone B analog, in patients with metastatic breast cancer previously untreated with taxanes. J Clin Oncol, 25:3421-7.

Dreicer R, Li S, Manola J, et al. 2007. Phase 2 trial of epothilone B analog BMS-247550 (ixabepilone) in advanced carcinoma of the urothelium (E3800): a trial of the Eastern Cooperative Oncology Group. Cancer, 110:759-63.

Eng C, Kindler HL, Nattam S, et al. 2004. A phase II trial of the epothilone B analog, BMS-247550, in patients with previously treated advanced colorectal cancer. Ann Oncol, 15:928-32.

Escuin D, Kline ER, Giannakakou P. 2005. Both microtubule-stabilizing and microtubule-destabilizing drugs inhibit hypoxia-inducible factor1alpha accumulation and activity by disrupting microtubule function. Cancer Res, 65:9021-8.

Esteve MA, Carre M, Braguer D. 2007. Microtubules in apoptosis induction: are they necessary? Curr Cancer Drug Targets, 7:713-29.

Faivre S, Delbaldo C, Boige V, et al. 2008. Safety of repeated administrations of ixabepilone given as a 3-hour infusion every other week in combination with irinotecan in patients with advanced malignancies. Eur J Cancer, 44:674-82.

Feldman DR, Kondagunta GV, Ginsberg MS, et al. 2007. Phase II trial of ixabepilone in patients with cisplatin-refractory germ cell tumors. Invest New Drugs, 25:487-90.

Feyen F, Cachoux F, Gertsch J, et al. 2008. Epothilones as lead structures for the synthesis-based discovery of new chemotypes for microtubule stabilization. Acc Chem Res, 41:21-31.

Fojo A, Menefee M, Poruchynsky M, et al. 2005. A translational study of ixabepilone (BMS-247550) in renal cell cancer (RCC): Assessment of its activity and demonstration of target engagement in tumor cells. Proc Am Soc Clin Oncol, 23:4541a.

Forster M, Kaye S, Oza A, et al. 2007. A phase Ib and pharmacokinetic trial of patupilone combined with carboplatin in patients with advanced cancer. Clin Cancer Res, 13:4178-84.

Fumoleau P, Coudert B, Isambert N, et al. 2007. Novel tubulin-targeting agents:anticancer activity and pharmacologic profile of epothilones and related analogues. Ann Oncol, 18(Suppl 5):v9-15. 
Gadgeel SM, Wozniak A, Boinpally RR, et al. 2005. Phase I clinical trial of BMS-247550, a derivative of epothilone B, using accelerated titration 2B design. Clin Cancer Res, 11:6233-9.

Galsky MD, Small EJ, Oh WK, et al. 2005. Multi-institutional randomized phase II trial of the epothilone B analog ixabepilone (BMS-247550) with or without estramustine phosphate in patients with progressive castrate metastatic prostate cancer. $J$ Clin Oncol, 23:1439-46.

Gatzemeier U, von Pawel J, Eschbach C, et al. 2007. Phase II trial of the novel epothilone ZK-EPO as second-line therapy in patients with stage IIIB or stage IV non-small cell lung cancer. Eur J Cancer Suppl, 5:6548a.

Gauler T, Christoph D, Gamarra F, et al. 2008. Phase I trial of the novel epothilone sagopilone (ZK-EPO) in combination with cisplatin as firstline therapy in patients with extensive-disease small-cell lung cancer (ED-SCLC). Proc Am Soc Clin Oncol, 26:19081a.

Gerth K, Bedorf N, Hofle G, et al. 1996. Epohtilons A and B: Antifungal and cytotoxic compounds from Sorangium cellulosum (Myxobacteria). Production, physico-chemical and biological properties. $J$ Antibiotics, 49:560-3.

Giannakakou P, Gussio R, Nogales E, et al. 2000. A common pharmacophore for epothilone and taxanes:molecular basis for drug resistance conferred by tubulin mutations in human cancer cells. Proc Natl Acad Sci U S A, 97:2904-9.

Goel S, Cohen M, Comezoglu SN, et al. 2008. The effect of ketoconazole on the pharmacokinetics and pharmacodynamics of ixabepilone: a first in class epothilone B analogue in late-phase clinical development. Clin Cancer Res, 14:2701-9.

Goodin S, Kane MP, Rubin EH. 2004. Epothilones:mechanism of action and biologic activity. $J$ Clin Oncol, 22:2015-25.

Graff J, Smith D, Neerukonda L, et al. 2008. Phase II study of sagopilone (ZK-EPO) plus prednisone as first-line chemotherapy in patients with metastatic androgen-independent prostate cancer (AIPC). Proc Am Soc Clin Oncol, 26:5141a.

Hao D, Hammond L, deBono J, et al. 2002. Continuous weekly administration of the epothilone-B derivative, BMS-247550 (NSC710428): A phase I and pharmacokinetic (PK) study. Proc Am Soc Clin Oncol, 21:411a.

Hoffmann J, Vitale I, Buchmann B, et al. 2008. Improved cellular pharmacokinetics and pharmacodynamics underlie the wide anticancer activity of sagopilone. Cancer Res, 68:5301-8.

Holen K, Syed S, Hannah A, et al. 2004. Phase I study using continuous intravenous (CI) KOS-862 (Epothilone D) in patients with solid tumors. Proc Am Soc Clin Oncol, 22:2024a.

Hsin K, Boyer M, Ducreux M, et al. 2006. Efficacy of patupilone in advanced local or metastatic gastric cancer: A phase IIa trial. Proc Am Soc Clin Oncol, 24:4069a.

Huang H, Menefee M, Edgerly M, et al. 2008. Ixabepilone (BMS-247550) and metastatic renal cell carcinoma (mRCC). Proc Am Soc Clin Oncol, 26:5053a.

Hussain A, Dipaola R, Baron A, et al. 2004. A Phase IIa trial of weekly EPO906 in patients with hormone-refractory prostate cancer (HPRC) Proc Am Soc Clin Oncol, 22:4563a.

Hussain M, Tangen CM, Lara PN Jr, et al. 2005. Ixabepilone (epothilone B analogue BMS-247550) is active in chemotherapy-naive patients with hormone-refractory prostate cancer: a Southwest Oncology Group trial S0111. J Clin Oncol, 23:8724-9.

Jacobs S, Fox B, Krailo M, et al. 2008. Phase II trial of ixabepilone (BMS247550) in children and young adults with refractory solid tumors: A report from the Children's Oncology Group. Proc Am Soc Clin Oncol, 26:10026a.

Kamath K, Wilson L, Cabral F, et al. 2005. BetaIII-tubulin induces paclitaxel resistance in association with reduced effects on microtubule dynamic instability. J Biol Chem, 280:12902-7.

Khawaja NR, Carre M, Kovacic H, et al. 2008. Patupilone-induced apoptosis is mediated by mitochondrial reactive oxygen species through Bim relocalization to mitochondria. Mol Pharmacol, in press.

Klar U, Buchmann B, Schwede W, et al. 2006. Total synthesis and antitumor activity of ZK-EPO: The first fully synthetic epothilone in clinical development. Angew Chem Int, 45:7942-8.
Kowalski RJ, Giannakakou P and Hamel E. 1997. Activities of the microtubule-stabilizing agents epothilones $\mathrm{A}$ and $\mathrm{B}$ with purified tubulin and in cells resistant to paclitaxel (Taxol(R)). J Biol Chem, 272:2534 41.

Lechleider R, Kaminskas E, Jiang X, et al. 2008. Ixabepilone in combination with capecitabine and as monotherapy for treatment of advanced breast cancer refractory to previous treatments. Clin Cancer Res, 14:4378-84.

Lee FY, Borzilleri R, Fairchild CR, et al. 2001. BMS-247550:a novel epothilone analog with a mode of action similar to paclitaxel but possessing superior antitumor efficacy. Clin Cancer Res, 7:1429-37.

Lee FY, Borzilleri R, Fairchild CR, et al. 2008. Preclinical discovery of ixabepilone, a highly active antineoplastic agent. Cancer Chemother Pharmacol, In press.

Lee JJ, Swain SM. 2008. The epothilones:translating from the laboratory to the clinic. Clin Cancer Res, 14:1618-24.

Lehne G. 2000. P-glycoprotein as a drug target in the treatment of multidrug resistant cancer. Curr Drug Targets, 1:85-99.

Low JA, Wedam SB, Lee JJ, et al. 2005. Phase II clinical trial of ixabepilone (BMS-247550), an epothilone B analog, in metastatic and locally advanced breast cancer. J Clin Oncol, 23:2726-34.

Magnani M, Ortuso F, Soro S, et al. 2006. The betaI/betaIII-tubulin isoforms and their complexes with antimitotic agents. Docking and molecular dynamics studies. Febs J, 273:3301-10.

Mani S, Huang H, Sundarababu S, et al. 2005. Activation of the steroid and xenobiotic receptor (human pregnane $\mathrm{X}$ receptor) by nontaxane microtubule-stabilizing agents. Clin Cancer Res, 11:6359-69.

Mani S, McDaid H, Hamilton A, et al. 2004. Phase I clinical and pharmacokinetic study of BMS-247550, a novel derivative of epothilone B, in solid tumors. Clin Cancer Res, 10:1289-98.

Mani S, McDaid HM, Grossman A, et al. 2007. Peripheral blood mononuclear and tumor cell pharmacodynamics of the novel epothilone B analogue, ixabepilone. Ann Oncol, 18:190-5.

Markman M. 2003. Managing taxane toxicities. Support Care Cancer, 11:144-7.

Mekhail T, Chung C, Holden S, et al. 2003. Phase I trial of novel epothilone B analog BMS-310705 IV q 21 days. Proc Am Soc Clin Oncol, 22:515a.

Mok TS, Choi E, Yau D, et al. 2006. Effects of patupilone (epothilone B; EPO906), a novel chemotherapeutic agent, in hepatocellular carcinoma: an in vitro study. Oncology, 71:292-6.

Monzo M, Rosell R, Sanchez JJ, et al. 1999. Paclitaxel resistance in non-small-cell lung cancer associated with beta-tubulin gene mutations. J Clin Oncol, 17:1786-93.

Moulder S, Wang M, Gradishar W, et al. 2007. A phase II trial of trastuzumab, weekly ixabepilone and carboplatin (TIC) in patients with HER2/neu-positive (HER2+) metastatic breast cancer (MBC): A trial coordinated by the Eastern Cooperative Oncology Group (E2103). Proc Am Soc Clin Oncol, 25:152a.

Nettles JH, Li H, Cornett B, et al. 2004. The binding mode of epothilone A on alpha,beta-tubulin by electron crystallography. Science, 305:866-9.

Nicolaou KC, Winssinger N, Pastor J, et al. 1997) Synthesis of epothilones A and B in solid and solution phase. Nature, 387:268-72.

Noguchi S. 2006. Predictive factors for response to docetaxel in human breast cancers. Cancer Sci, 97:813-20.

O'Brien C, Cavet G, Pandita A, et al. 2008. Functional genomics identifies $\mathrm{ABCC} 3$ as a mediator of taxane resistance in HER2-amplified breast cancer. Cancer Res, 68:5380-9.

O'Connor O, Straus D, Moskowitz C, et al. 2005. Targeting the microtubule apparatus in indolent and mantle cell lymphoma with the novel epothilone analog BMS247550 induces major and durable remissions in very drug resistant disease. Proc Am Soc Clin Oncol, 23:6569a.

Okuno S, Maples WJ, Mahoney MR, et al. 2005. Evaluation of epothilone $\mathrm{B}$ analog in advanced soft tissue sarcoma:a phase II study of the phase II consortium. J Clin Oncol, 23:3069-73.

Pavlick A, Millward M, Farrell K, et al. 2004. A phase II study of epothilone B analog (EpoB)-BMS 247550 (NSC\#710428) in stage IV malignant melanoma (MM). Proc Am Soc Clin Oncol, 22:7542a.

Pellegrini F and Budman DR. 2005. Review:tubulin function, action of antitubulin drugs, and new drug development. Cancer Invest, 23:264-73. 
Perez EA, Lerzo G, Pivot X, et al. 2007. Efficacy and safety of ixabepilone (BMS-247550) in a phase II study of patients with advanced breast cancer resistant to an anthracycline, a taxane, and capecitabine. $J$ Clin Oncol, 25:3407-14.

Peterson JK, Tucker C, Favours E, et al. 2005. In vivo evaluation of ixabepilone (BMS247550), a novel epothilone B derivative, against pediatric cancer models. Clin Cancer Res, 11:6950-8.

Piro L, Rosen L, Parson M, et al. 2003. KOS-862 (epothilone D): A comparison of two schedules in patients with advanced malignancies. Proc Am Soc Clin Oncol, 22:539a.

Poplin E, Moore M, O'Dwyer P, et al. 2003. Safety and efficacy of EPO906 in patients with advanced colorectal cancer: A review of 2 phase II trials. Proc Am Soc Clin Oncol, 22:1135a.

Posadas EM, Undevia S, Manchen E, et al. 2007. A phase II study of ixabepilone (BMS-247550) in metastatic renal-cell carcinoma. Cancer Biol Ther, 6:490-3.

Pusztai L. 2007. Markers predicting clinical benefit in breast cancer from microtubule-targeting agents. Ann Oncol, 18(Suppl 12):xii15-20.

Reese M, Sanchez-Pedregal V, Blommers M, et al. 2006. Pharmacophore mapping by the novel Inpharma method:The epothilone tubulin complex. First European Chemistry Congress. 194a

Reid T, Takimoto C, Verschraegen C, et al. 2008. Evaluation of safety, tolerability and pharmacokinetics (PK) of patupilone in patients with advanced solid tumors and varying degrees of hepatic function: An open-label phase I study. Proc Am Soc Clin Oncol, 26:2557a.

Roche H, Yelle L, Cognetti F, et al. 2007. Phase II clinical trial of ixabepilone (BMS-247550), an epothilone B analog, as first-line therapy in patients with metastatic breast cancer previously treated with anthracycline chemotherapy. J Clin Oncol, 25:3415-20.

Rosenberg JE, Weinberg VK, Kelly WK, et al. 2007. Activity of secondline chemotherapy in docetaxel-refractory hormone-refractory prostate cancer patients: randomized phase 2 study of ixabepilone or mitoxantrone and prednisone. Cancer, 110:556-63.

Rubin EH, Rothermel J, Tesfaye F, et al. 2005. Phase I dose-finding study of weekly single-agent patupilone in patients with advanced solid tumors. J Clin Oncol, 23:9120-9.

Sakaushi S, Nishida K, Fukada T, et al. 2008. Differential response of mitotic spindle pole formation to microtubule-stabilizing agents epothilone A and B at low concentrations. Cell Cycle, 7:477-83.

Schmid P, Kiewe P, Kuehnhardt D, et al. 2005. A phase I study of the novel, third generation epothilone ZK-EPO in patients with advanced solid tumors. Proc Am Soc Clin Oncol, 23:2051a.

Sessa C, Perotti A, Llado A, et al. 2007. Phase I clinical study of the novel epothilone B analogue BMS-310705 given on a weekly schedule. Ann Oncol, 18:1548-53.

Sessa C, Perotti A, Malossi A, et al. 2003. Phase I and pharmacokinetic (PK) study of the novel epothilone BMS-310705 in patients (pts) with advanced solid cancer. Proc Am Soc Clin Oncol, 22:519a.

Seve P, Mackey J, Isaac S, et al. 2005. Class III beta-tubulin expression in tumor cells predicts response and outcome in patients with non-small cell lung cancer receiving paclitaxel. Mol Cancer Ther, 4:2001-7.

Seve P, Reiman T, Isaac S, et al. 2008. Protein abundance of class III betatubulin but not Delta2-alpha-tubulin or tau is related to paclitaxel response in carcinomas of unknown primary site. Anticancer Res, 28:1161-7.

Shah R, Kaye S. 2003. In: Handbook of Anticancer Drug Development. Budman, DR, Calvert A, Rowinsky E (eds). Baltimore: Lippincott, Williams and Wilkins. pp. 13-24.

Shimizu T, Yamamoto N, Yamada Y, et al. 2008. Phase I clinical and pharmacokinetic study of 3-weekly, 3-h infusion of ixabepilone (BMS247550), an epothilone B analog, in Japanese patients with refractory solid tumors. Cancer Chemother Pharmacol, 61:751-8.

Silvani A, Fiumani A, Scaioli V, et al. 2008. A phase II study evaluating systemic sagopilone (ZK-EPO) treatment in patients with recurrent malignant gliomas. Proc Am Soc Clin Oncol, 26:2083a.

Singh D, Taber D, Ansari R, et al. 2006. A phase II trial of the epothilone B analog BMS-247550 in patients (pts) with hepatobiliary cancer (HBC): An updated analysis. Proc Am Soc Clin Oncol, 24:14050a.
Smit W, Sufliarsky J, Spanik S, et al. 2005. Phase I/II dose-escalation trial of patupilone every 3 weeks in patients with relapsed/refractory ovarian cancer. Proc Am Soc Clin Oncol, 23:5056a.

Smith S, Pro B, van Besien K, et al. 2005. A phase II study of epothilone B analog BMS-247550 (NSC 710428) in patients with relapsed aggressive non-Hodgkin's lymphomas. Proc Am Soc Clin Oncol, 23:6625a.

Spriggs D, Dupont J, Pezzulli S, et al. 2003. KOS-862 (epothilone D): Phase I dose escalating and pharmacokinetic (PK) study in patients with advanced malignancies. Proc Am Soc Clin Oncol, 22:894a.

Spriggs D, Soignet S, Bienvenu B, et al. 2001. Phase 1 first-in-man study of epothilone B analog BMS-247550 in patients with advanced cancer. Proc Am Soc Clin Oncol, 20:428a.

Stopeck A, Moulder S, Jones S, et al. 2007. Phase I trial of KOS-1584 (a novel epothilone) using two weekly schedules. Proc Am Soc Clin Oncol, 25:2571a.

Stopeck A, Thomas E, Jones S, et al. 2006. Phase I trial of a novel epothilone, KOS-1584, using a weekly dosing schedule. Proc Am Soc Clin Oncol, 24:2041a.

Stupp R, Tosoni A, Taal W, et al. 2008. Phase II trial of the epothilone analog sagopilone (ZK219477; ZK EPO) in patients with recurrent glioblastoma:Initial report of the EORTC study 26061. Proc Am Soc Clin Oncol, 26:2015a.

Takimoto C, Fu S, Dhillon N, et al. 2008. Evaluation of pharmacokinetics $(\mathrm{PK})$ and pharmacodynamics (PD) of patupilone and warfarin in patients (pts) with advanced solid tumors:An open-label, phase I study. Proc Am Soc Clin Oncol, 26:2548a.

Thomas E. 2008. Ixabepilone plus capecitabine for metastatic breast cancer progressing after anthracycline and taxane treatment. $J$ Clin Oncol, 26:2223.

Thomas E, Tabernero J, Fornier M, et al. 2007a. Phase II clinical trial of ixabepilone (BMS-247550), an epothilone B analog, in patients with taxane-resistant metastatic breast cancer. $J$ Clin Oncol, 25:3399-406

Thomas ES, Gomez HL, Li RK, et al. 2007b. Ixabepilone plus capecitabine for metastatic breast cancer progressing after anthracycline and taxane treatment. J Clin Oncol, 25:5210-7.

Thompson J, Swerdloff J, Escudier B, et al. 2003. Phase II trial evaluating the safety and efficacy of EPO906 in patients with advanced renal cancer. Proc Am Soc Clin Oncol, 22:1628a.

Vansteenkiste J, Lara PN, Jr. Le Chevalier T, et al. 2007. Phase II clinical trial of the epothilone $\mathrm{B}$ analog, ixabepilone, in patients with non smallcell lung cancer whose tumors have failed first-line platinum-based chemotherapy. J Clin Oncol, 25:3448-55.

Villalona-Calero M, Goel S, Schaaf L, et al. 2006. First-in-human phase I trial of a novel epothilone, KOS-1584. Proc Am Soc Clin Oncol, 24:2003a.

Wenk D, Deconti R, Urbas P, et al. 2008. Phase II trial of sagopilone (ZKEPO), a novel epothilone, in patients with metastatic melanoma. Proc Am Soc Clin Oncol, 26:9046a.

Whitehead RP, McCoy S, Rivkin SE, et al. 2006. A phase II trial of epothilone B analogue BMS-247550 (NSC \#710428) ixabepilone, in patients with advanced pancreas cancer:a Southwest Oncology Group study. Invest New Drugs, 24:515-20.

Wilding G, Chen Y, DiPaola R, et al. 2008. E3803:Updated results on phase II study of a weekly schedule of BMS-247550 for patients with castrate refractory prostate cancer (CRPC). Proc Am Soc Clin Oncol, 26:5070a.

Yee L, Lynch T, Villalona-Calero M, et al. 2005. A phase II study of KOS862 (Epothilone D) as second-line therapy in non-small cell lung cancer Proc Am Soc Clin Oncol, 2005:7127a.

Zhuang SH, Agrawal M, Edgerly M, et al. 2005. A Phase I clinical trial of ixabepilone (BMS-247550), an epothilone B analog, administered intravenously on a daily schedule for 3 days. Cancer, 103:1932-8

Zhuang SH, Hung YE, Hung L, et al. 2007. Evidence for microtubule target engagement in tumors of patients receiving ixabepilone. Clin Cancer Res, 13:7480-6. 
